\title{
SPATIAL PATTERNS AND SUCCESSION IN A MINNESOTA SOUTHERN-BOREAL FOREST ${ }^{1}$
}

\author{
Lee E. Frelich and Peter B. Reich \\ Department of Forest Resources, University of Minnesota, St. Paul, Minnesota 55108 USA
}

\begin{abstract}
Succession was studied in a cold-temperate forest in the Boundary Waters Canoe Area Wilderness (BWCAW) of northeastern Minnesota. The $13 \times 18 \mathrm{~km}$ study area comprises a complex forest mixture of jack (Pinus banksiana) and other pines, quaking aspen (Populus tremuloides), paper birch (Betula papyrifera), black spruce (Picea mariana), balsam fir (Abies balsamea), and white cedar (Thuja occidentalis) on thin soils over the Canadian Shield bedrock. The main objectives of this study were to examine the relationships between spatial patchiness, spatial scale, and canopy succession in the southern-boreal forest of the BWCAW, and to evaluate under what conditions successional direction may remain stable, converge, or diverge. Knowledge of the successional direction of old forests in the BWCAW that are undergoing demographic transition from evenaged to uneven-aged is important because the landscape now has many old stands as a result of reduced fire frequency. Rotation periods for fires have changed from $\approx 50-100 \mathrm{yr}$ in presettlement times to $>1000 \mathrm{yr}$ since 1910.
\end{abstract}

Analyses were conducted at spatial scales ranging from the individual tree ( $0.01 \mathrm{ha})$ to the large stand (16 ha). Two permanent mapped plots (of area 0.53 and 0.56 ha) were established in stands of different age. Finescale age structure, successional change, transition from one species to another, and development of small patches (of area $<0.25 \mathrm{ha}$ ) were studied by means of stand history reconstruction with increment cores, spatial autocorrelation, and analysis of replacement trees in canopy openings. Spatial processes at nested scales of 1,4 , and 16 ha were examined on 15 square 16-ha tracts of upland forest, which are distributed among forests ranging from 15 to $190 \mathrm{yr}$ old. Canopy species composition and patch development over time on these 15 tracts were interpreted on air photos taken in 1934,1961, and 1991. Thus, the study includes a chronosequence approach, with verification of chronosequence validity by checking patch development processes at more than one time point. This checking was done at small spatial scales by reconstruction of stand history on permanent mapped plots, and at larger spatial scales with sequential air photos of the same locations spanning a 57-year period.

Results show that the reduced fire frequency in recent years has changed the dominant successional pathways. When fire frequency was high, jack pine or aspen stands usually burned while still in the even-aged stage of development, and the new trees after the burn were the same species as before. Currently, many stands are undergoing demographic transition from even-aged stands of catastrophic fire origin to uneven-aged stands. This transition parallels a change in canopy composition from jack pine (occasionally red pine (Pinus resinosa)) or aspen to an old-growth multi-aged mixture of black spruce, balsam fir, paper birch, and white cedar. The mechanism that moves this successional path forward is canopy openings, $10-30 \mathrm{~m}$ across on average, caused by wind, insect, and disease, that gradually chip away at the relatively uniform canopy of pines and aspen. Successional direction is individualistic in the sense that time and rate of transition from pine/aspen to other species depends on the action of heavy windstorms, insect infestation, and senescence of old pines that create canopy openings. Canopy openings are often filled with one of several species, but if more than one species invades an opening, monodominant patches of each species generally result. Understory-overstory interactions are very weak; the dominant species within each patch is apparently independent of the overstory species that died when the opening was created or the species dominating surrounding patches. During succession, the spatial structure of the stands at the 1-16 ha scales generally changes from a matrix heavily dominated by pine or aspen to a mosaic with relatively large mono-dominant patches that may be remnants of the extensive original matrix, and finally to a mixture with small patches (mean area $35 \mathrm{~m}^{2}$, maximum $\approx 0.1$ ha) of black spruce, balsam fir, white cedar, and paper birch. Thus, at 1-16 ha spatial scales, succession leads to convergence on a mixture of species. At smaller spatial scales (e.g., 0.01-0.1 ha) successional pathways appear to diverge into four community types. The same successional pathways can be reconstructed from historical analysis of individual stands as from a chronosequence of stands; therefore, chronosequences in this area have been stable at least during the lifetime of the current generation of trees.

Key words: Balsam fir; Boundary Waters Canoe Area Wilderness; chronosequence; jack pine; natural disturbance; paper birch; patch dynamics; red pine; successional convergence; successional divergence; successional pathways; white cedar.

\footnotetext{
${ }^{1}$ Manuscript received 2 May 1994; revised 10 October 1994; accepted 24 October 1994; final version received 16 November 1994.
} 


\section{INTRODUCTION}

This study focuses on succession in an unlogged cold-temperate forest in the Boundary Waters Canoe Area Wilderness (BWCAW) of northeastern Minnesota. Forests in the study area comprise a complex mixture of boreal and near-boreal species. This mixture includes species with several adaptations to fire: rootsprouting ability and abundant seeds with good longdistance dispersal (quaking aspen, Populus tremuloides and paper birch, Betula papyrifera); serotinous cones stored high in the canopy (jack pine, Pinus banksiana and black spruce, Picea mariana); or thick bark that allows individuals to survive fires and reseed the area later (red pine, Pinus resinosa). In the past, natural fire regimes have given the advantage to these species so that they were dominant over large portions of the BWCAW. Advance regeneration by understory-tolerant species such as balsam fir (Abies balsamea), white cedar (Thuja occidentalis), and white spruce (Picea glau$c a)$ was sparse and these species were commonly removed by fire before becoming very abundant in most stands (Carleton and Maycock 1978, Johnson 1992).

Historically, the rotation period for catastrophic fires in the BWCAW had been $\approx 50-100$ years (Heinselman 1973), less than the potential life-span of the tree species, so that fire-adapted species listed above dominated at all stages of stand development. Since 1910, the rotation period has lengthened considerably, and is now substantially longer than maximum tree life-spans (Heinselman 1973). The cause of reduction in fire frequency is not certain at this time, but several possibilities exist. These include fire suppression (Heinselman 1973), a climate less conducive to fire in recent years (Johnson 1992), and land use changes around the BWCAW that no longer allow fires to start outside the BWCAW and burn into it from the south or west (a common pattern prior to settlement).

Under the reduced fire frequency of recent years, successional patterns are relatively unknown. Post-fire stands of aspen/birch or red/jack pine are replaced by a mixture of species, including shade-tolerant and shade-intolerant species. Previous studies have predicted that fir-spruce-birch can form a self-maintaining community (Buell and Niering 1957), or that spruce and birch can form a mosaic of small patches that undergo reciprocal replacement due to the feedbacks of each species on soil nutrients (Pastor et al. 1987). Another alternative was suggested by Grigal and Ohmann (1975), who found that upland white cedar forests in the BWCAW were not edaphically determined, but rather occupied areas that had not burned for longer time periods than any other forest type. They produced a canonical ordination showing that white cedar may be the ultimate climax species in the BWCAW. However, Heinselman $(1973,1981 a, b)$ observed that some stands that by chance escaped disturbance for 350 years have still not succeeded from pines or black spruce to white cedar and balsam fir, and questioned the validity of the classical succession concept in boreal forests.

Predicting the direction of succession in forests has been a major focus of ecological research (e.g., Gleason 1927, Clements 1936, Watt 1947, Curtis 1959, Drury and Nisbet 1973, Horn 1974, West et al. 1981, Christensen and Peet 1984, Peet 1992). In our view, five directional models of succession have emerged from the literature:

1) Cyclic model. Vegetation starts in state (community or species) $A$, then proceeds to state $B, C$, etc., eventually returning to state $A$. First proposed by Watt (1947), this has been one of the major models employed by ecologists. An example is aspen invading an area after intense fire, followed by red maple and other species of intermediate shade tolerance, and finally by shade-tolerant northern hardwoods and hemlock, which then persist until another fire resets the cycle to aspen (Lorimer 1977, Whitney 1986, Frelich 1992).

2) Convergent model. This is the classic model of Clements (1936), in which vegetation in two or more states $(A$ and $B$ ) both converge over time to state $C$. An example would be two postfire stands dominated by early- or mid-successional species such as aspen and white pine (Pinus strobus), respectively, which both succeed to shade-tolerant northern hardwoods. Convergence and divergence may both occur during the same successional sequence, but at different times (Christensen and Peet 1984).

3) Divergent model. One community (state $A$ ) diverges into two or more states $(B, C$, etc.), over time. The divergence involves feedback switches that magnify initial minor differences, and, once the differences are large, allow their perpetuation (Wilson and Agnew 1992). Davis et al. (1994) describe a Pinus strobusAcer rubrum-Quercus rubra forest that succeeded over a 1000-year period into mono-dominant patches of either Acer saccharum or Tsuga canadensis, after the forest was invaded in a patchy manner by Tsuga. The Tsuga invasion led to a change in fuel type that reduced fire frequency, allowing $A$. saccharum to dominate areas between the Tsuga patches. The A. saccharum and Tsuga in turn each produce a forest floor environment unfavorable to establishment of other species, so that the patches are maintained.

4) Parallel model. Communities of states $A$ and $B$ each undergo disturbance, and each returns to the same state shortly after the disturbance. Parallel succession is common in much of the boreal forest, since species like jack pine or black spruce can be the overwhelming dominant over large areas. When stand-killing fires occur in such areas, the species in the prefire stand are the only seed source, so that the postfire stand still maintains the same overstory composition (Dix and Swan 1971, Heinselman 1981 $a, b$, Johnson 1992). Fires will burn much of the forest floor moss cover, and there 
will be successional changes in ground flora species composition (Heinselman 1981b), but not necessarily the dominant tree species of interest here.

5) Individualistic model. Also called multiple pathways (Cattelino et al. 1979), individualistic succession occurs when stochastic variables (such as timing of seed years of dominant trees, droughts, and disturbances) interact to produce multiple pathways of succession at different times at the same location. This model emphasizes continuous change and there is not a stable endpoint. For example, a gap in the forest canopy formed in one decade could be filled by paper birch, merely because paper birch had a good seed year and other species did not. If the paper birch later die of old age during a drought, they may be replaced by a species with drought-tolerant seedlings, such as white cedar, if that species is nearby and has a good seed year.

Factors that may obscure our ability to predict direction of succession in the boreal forest, or even determine which of the five models above are appropriate, are: (1) lack of spatial context, (2) inadequate consideration of spatial scale, and (3) inadequate knowledge of successional mechanisms. Reviews of succession (Drury and Nisbet 1973, Facelli and Pickett 1990) suggest that the spatial context in which succession occurs is not adequately taken into account in many studies. Neighborhood effects, such as seed rain, nutrient feedbacks on the soil through litterfall, and shading, may all play a role in determining how succession proceeds. Although a number of recent studies attempt to integrate spatial effects into successional studies (e.g., Lippe et al. 1985, Hubbell and Foster 1986, Smith and Huston 1989, Frelich et al. 1993), studies of this sort have not been accomplished in the BWCAW.

Research on forest succession often concentrates on processes that occur at a single spatial scale. For example, a large number of papers have been published that examine individual tree gaps (e.g., Runkle 1982) or that examine stands (e.g., Grigal and Ohmann 1975) or that analyze landscapes (e.g., Payette et al. 1989, Dansereau and Bergeron 1993). An example of the data interpretation difficulties this may create is apparent in the fir-spruce-birch forest report of Buell and Niering (1957). This forest may be a uniformly mixed forest, with individual trees of different species next to each other (the result of convergent succession), or a series of small mono-dominant stands (the result of divergent succession). However, since no spatial data are presented, this is impossible to ascertain. In addition, a series of small mono-dominant stands at a small spatial scale may appear to be a mixed stand when looked at over a larger area, with a larger minimum mapping unit.

Few studies attempt to link processes occurring at the individual tree scale with stand and larger spatial scales. This paper, while it does not offer comprehensive integration across all spatial scales in the BWCAW, does cover changes at spatial scales across four orders of magnitude from individual tree (0.01 ha) to large stands or groups of stands ( $16 \mathrm{ha}$ ). Spatial patterns at larger orders of magnitude (i.e., hundreds to thousands of hectares) in the BWCAW depend on the interaction between large, intense fires and topographical features such as lakes. These large patches are beyond the scope of this paper, but are covered by Heinselman (1973), Baker (1989), and Johnson (1992).

The main objective of this study was to examine the relationships between spatial patchiness, spatial scale, and canopy succession in the southern-boreal forest of the BWCAW, and secondarily to evaluate under what conditions any of the five models of successional direction are valid. We will develop a conceptual model of successional dynamics. Of special interest will be the changes in stand spatial structure and species composition that occur during the demographic transition from even-aged to uneven-aged. Knowledge of the successional direction of forests in the BWCAW after demographic transition is important because the landscape now has many old stands as a result of reduced fire frequency. In this paper, we mainly examine demographic data; future studies will relate succession to physiographic and environmental factors.

\section{StUdy AREA}

The study area $(\approx 13 \times 18 \mathrm{~km}$; Fig. 1$)$ is located at $90^{\circ} 50^{\prime} \mathrm{W}$ longitude and $48^{\circ} 20^{\prime} \mathrm{N}$ latitude, within the Boundary Waters Canoe Area Wilderness (BWCAW), a 400000 ha component of the national wilderness preservation system and part of Superior National Forest. The area has low-relief and gently rolling topography with a complicated network of glaciated lakes on granitic Canadian Shield bedrock. The climate is cold-temperate continental, with a mean growing season length of $\approx 100$ days. Summers are cool and rainy in most years, with $10-20$ rain days/mo from June through September, and mean July temperature of $17^{\circ} \mathrm{C}$. Winters are long and cold; the ground is snow-covered from early November to late April and the mean January temperature is $-17^{\circ}$ (Ahlgren 1969).

The vegetation type is an unlogged mixture of conifers with paper birch and aspen, referred to as "near boreal forest" by Heinselman (1973). The natural disturbance regime originally consisted of catastrophic crown or intense ground fires with rotation periods dependent on the dominant species and site: $\approx 50$ years in jack pine, $\approx 100$ years in spruce-aspen-birch, and 150-200 years in red and white pine (Heinselman 1973, 1981a). The red and white pine also had light surface fires every $20-40$ years. Within the study area are large (100-1000 ha) patches of forest that originated after major canopy-killing fires in $1801,1815,1854,1864$, 1903, 1910, 1974, and 1976 (Heinselman 1973). Other disturbances common in the area include spruce and budworm (Choristoneura fumiferana (Clem.)), which commonly kills patches of canopy balsam fir in older stands, often leaving many live seedlings and saplings 


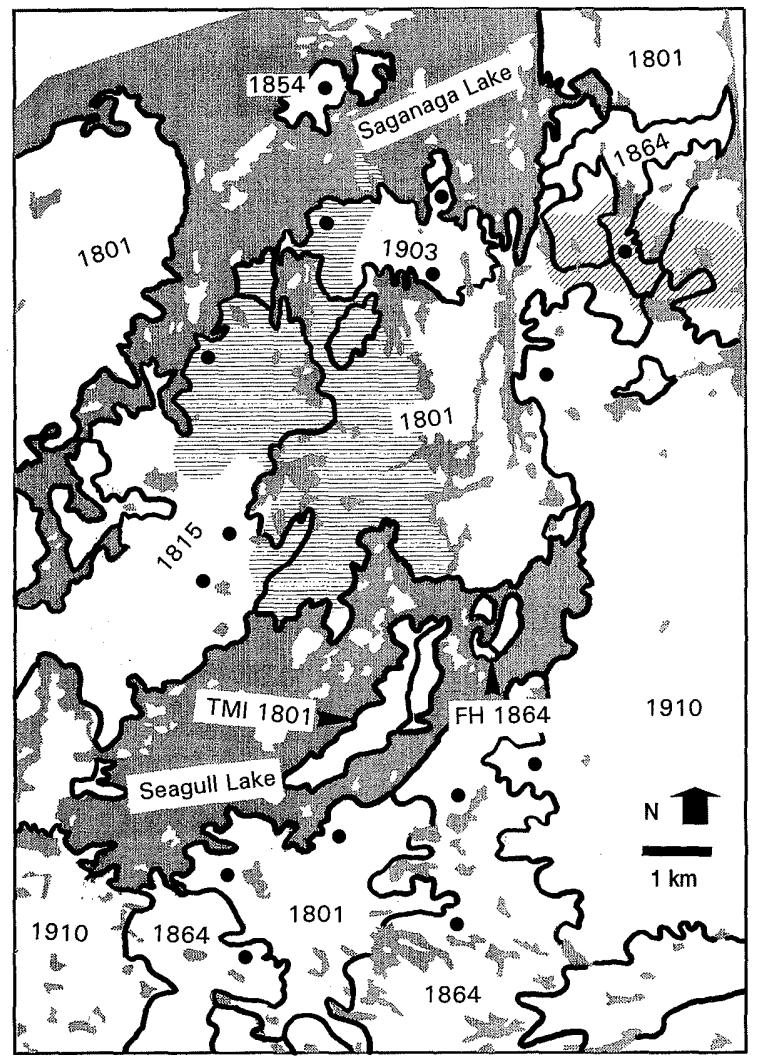

FIG. 1. Map of the Seagull Lake study area. Dark shading indicates water. Heavy black lines delimit stands originating after catastrophic fires from 1801 to 1910 (for clarity, only the stands relevant to this paper are labeled; small stands and islands are unlabeled). Light horizontal hatching shows the area of stand-killing fires in 1976, which burned parts of stands previously burned in 1801, 1815, and 1903 (see Table 7). Diagonal hatching covers the area burned in 1974. The two arrows in Seagull Lake, labeled TMI 1801 and FH 1864 point to the locations of the Threemile Island and Fishook Island permanent mapped plots/ground study areas, respectively. Dots mark the air photo study sites.

(Ohmann and Ream 1971). Wind in the BWCAW may blow down individual large trees or level whole stands (rotation period $>1000$ years) during summer thunderstorm downbursts. Widespread tree mortality, especially in black spruce, balsam fir, and paper birch stands with tall spindly trees, occurs during fall and spring storms with heavy wet snow and high winds.

Two sites within the study area were selected for detailed analysis. The Threemile Island site in Seagull Lake is covered with forest originating in 1801 . The 3 -ha study site includes a 0.53 ha permanent stemmapped plot with a mixed forest dominated by red pine, jack pine, black spruce, white cedar, paper birch, and balsam fir. Other minor components include quaking aspen, white pine, white spruce, mountain ash (Sorbus decora), and mountain maple (Acer spicatum). The site has $6 \mathrm{~m}$ of relief with small granite knobs, and the north edge is $20 \mathrm{~m}$ south of the shore of Seagull Lake. Soils consist of pockets of loamy coarse sand, a few metres in horizontal extent and $10-20 \mathrm{~cm}$ thick, and areas of feathermoss (mainly Hypnum crista-castrensis, Hylocomium splendens) 2-20 cm thick on top of bedrock.

The second detailed study site, Fishook Island, includes jack pine, black spruce and paper birch forest originating in 1864. Balsam fir, white cedar, quaking aspen, white pine, and white spruce occur as minor components of this forest. The study site is 1 ha in area, with a 0.56 -ha permanent stem-mapped plot. Soil consists of about $10 \mathrm{~cm}$ of loam over $10-30 \mathrm{~cm}$ of coarse sand with gravel and cobbles. Small areas with no mineral soil also occur, and these are covered with feathermoss $\leq 20 \mathrm{~cm}$ thick.

\section{METHODS \\ General}

Analyses were conducted at spatial scales ranging from the individual tree to the large stand. First, two permanent mapped plots (of area 0.53 and 0.56 ha) were established in stands of different ages to look at fine-scale age structure, transition from understory to canopy and from one species to another, and development of small patches (of area $<0.25$ ha). Each of the two permanent mapped plots is embedded within a ground study site, which is a 1-3 ha area of contiguous similar forest. The purpose of the ground study sites was to provide additional information on transition probabilities in gaps because there were not enough gaps on a permanent plot for adequate sample size. The dynamics of the entire $13 \times 18 \mathrm{~km}$ study area were sampled using 15 square 16 -ha tracts of upland forest referred to as air photo study sites, which are distributed among forests ranging from 15 to 190 years old. Air photo study sites do not include the permanent mapped plots; however, the air photos of the permanent mapped plots were checked to see that patch development interpreted on photos is consistent with patch development as reconstructed by age structure analysis. Interpretation of air photos from 1934, 1961, and 1991 was used to quantify development of large patches (of area $>0.25 \mathrm{ha}$ ), as forest on the same air photo study site develops over time. Thus, the study includes a chronosequence approach, with verification of chronosequence validity by checking patch development processes at more than one time point. This checking was done at small spatial scales by reconstruction of stand history on permanent mapped plots, and at larger spatial scales with sequential air photos of the same locations spanning a $57-y r$ period.

\section{Permanent mapped plots}

Mapping.-On the two permanent mapped plots, all woody stems $>1.4 \mathrm{~m}$ in height were mapped $(n=2063$ at Threemile Island, 1064 at Fishook Island). Most trees $>5 \mathrm{~cm}$ dbh were mapped with a Topcon surveying station, which yields $x$ and $y$ coordinates and elevation, 
with an accuracy within $0.1-0.5 \mathrm{~m}$ of the true location relative to the base corner of the plot. Smaller trees (as well as a few larger trees that were in locations of poor visibility so that they could not be seen from the surveying station), were mapped by measuring distance and azimuth from the nearest of the trees accurately located with the surveying station. On average, the distances of these smaller trees from one of the trees mapped with the surveying station was $<2 \mathrm{~m}$. Diameter at $1.4 \mathrm{~m}(\mathrm{dbh})$, species, and crown class were recorded for each tree. Crown classes used were canopy (trees receive direct sunlight on the crown from above), understory (tree does not receive direct sunlight), and dead (standing dead or snagged).

Increment cores.-To assess the spatial extent and pattern of various cohorts, the nearest canopy tree (at Threemile Island) or nearest two canopy trees (at Fishook Island) were cored at regularly spaced grid points. The grid points were $7 \mathrm{~m}$ apart at Threemile Island, resulting in 109 increment cores, and $10 \mathrm{~m}$ apart at Fishook Island, resulting in 104 increment cores. Because of the high frequency of heart rot at the base of trees, cores were taken at a height of $1.0 \mathrm{~m}$. Cores were considered complete if they terminated within $2 \mathrm{~cm}$ of the center of the tree, in which case the total age at 1.0 $\mathrm{m}$ was corrected by extrapolating the growth rate from the earliest five years on the core all the way to the center. In general, if a given core was not complete, a second core was attempted from the same tree, and if no complete core could be obtained, the next nearest tree was cored. In several cases, a core was obtained that did not come within $2 \mathrm{~cm}$ of the pith, but the core was retained because there was a potentially useful release from suppression recorded on the core. The increment cores were stored in straws, dried, sanded, mounted on wooden holders, and ring widths were read at $\geq 10 \times$ magnification.

Decade of canopy accession was estimated for each cored tree based on (1) release from suppression $(\geq 100 \%$ increase in radial growth sustained for $\geq 15$ years), or (2) rapid growth in the early years or an arched-shaped or continuously declining pattern throughout the life of a tree indicating the tree was in a gap by the time it reached $1.0 \mathrm{~m}$ in height. The rules were based on techniques in Lorimer et al. (1988) and Lorimer and Frelich (1989).

Disturbance chronologies. - The disturbance chronology, comprising the distribution of canopy turnover by decade, was estimated by $(x / n)(100)$, where $x$ was the number of trees showing a canopy accession during a given decade and $n$ was the number of trees in the sample. Because the trees chosen for coring were selected at regular grid points, the resulting disturbance chronology represents the proportion of the study area currently occupied by cohorts originating in each decade and not necessarily the proportion of the plot occupied by each cohort at the time of its origin (Frelich and Martin 1988). In some cases, one tree showed two releases from suppression, and was thus counted twice in the disturbance chronology.

Coarse woody debris.-The species, number, and size of logs on the forest floor were tallied to estimate stand density prior to canopy breakup upon entering the re-initiation stage (Oliver 1981) of stand development. Re-initiation appears to have begun $\approx 1900$ on the Threemile Island plot and within the last decade at Fishook Island (see Results: Permanent mapped plots and ground study sites). Decay of pine logs in northern Minnesota can take 50-100 years (as evidenced by age of trees growing on $\operatorname{logs}$ ), so that many of the trees from the original cohort in each stand (1801 or 1864) are still present on the forest floor. We walked $\approx 300$ $m$ of transect lines on each plot, tallying all intact $\log s$ $>10 \mathrm{~cm}$ in diameter with the root crown within $2 \mathrm{~m}$ of the transect line. Older $\operatorname{logs}$ that were physically broken down and part of the forest floor were not tallied. In most cases, the species could be identified. The $\mathrm{dbh}$ and length of each $\log$ were measured with a tape.

Overstory-understory abundance relationships.Both mapped plots were divided into contiguous $15 \times$ $15 \mathrm{~m}$ blocks to look at local variation in tree abundance ( $n=23$ blocks at Threemile Island and 25 blocks at Fishook Island). Only blocks that were fully inside the mapped plot boundaries were used on the Threemile Island mapped plot, which has an irregular shape. Basal area of each species was summed separately for overstory and understory trees within each block. Graphs of understory tree basal area as a function of overstory tree basal area were examined for each species combination. We attempted to fit regressions to each relationship using standard least squares techniques.

Spatial pattern analysis.-Spatial patterns of tree ages on the two plots were examined with Moran's I (Sokal and Oden 1978), a two-dimensional analog of the standard correlation coefficient. Positive values of Moran's I above the critical value (95\% confidence in this case) indicate clumping for a given distance class. Typically, Moran's I is calculated for successive distance classes, resulting in a correlogram that shows degree of clustering by distance class. A correlogram showing significant clumping usually starts with high correlation at short distances and gradually descends to insignificant levels at some further distance (e.g., trees within a few metres of a given tree are more likely to be similar in age than trees farther away). The distance class at which Moran's I is no longer significantly positive can be considered the average patch diameter (Sokal and Oden 1978). Correlograms here were prepared for date of canopy accession of trees for $10-\mathrm{m}$ distance classes. The assumptions made for statistical application of spatial autocorrelation are that the spatial patterns being analyzed are isotropic (i.e., have no directional component) and homogeneous throughout the area under analysis (e.g., there are not big patches at one end of the plot and small ones at the other end).

Spatial autocorrelation was also used to detect as- 
TABLE 1. Presence of stands by age class on photos taken in 1934, 1961, and 1991. Stand origin dates are broken into four pairs that serve as replicate analyses for each age category. Parentheses in first column show the number of air photo study sites located in stands of each origin date. The stands that burned in 1974 or 1976 (young in 1991) originated in 1801, 1815,1864 , or 1903 .

\begin{tabular}{|c|c|c|c|}
\hline \multirow[b]{2}{*}{ Year of stand origin* } & \multicolumn{3}{|c|}{ Year air photos taken } \\
\hline & 1934 & 1961 & 1991 \\
\hline & \multicolumn{3}{|c|}{ Age of stands on air photos (yr) } \\
\hline Pair 1: $1801(2) ; 1815(2)$ & $\begin{array}{c}119-133 \\
\text { old } \dagger\end{array}$ & $\begin{array}{c}146-160 \\
\text { very old } \dagger\end{array}$ & $\begin{array}{l}176-190 \\
\text { very old }\end{array}$ \\
\hline Pair 2: $1854(1) ; 1864(3)$ & $\begin{array}{l}70-80 \\
\text { mature } \dagger\end{array}$ & $\begin{array}{l}97-107 \\
\text { old }\end{array}$ & $\begin{array}{c}127-137 \\
\text { old }\end{array}$ \\
\hline Pair 3: 1903 (2); $1910(2)$ & $\begin{array}{c}31-38 \\
\text { young } \dagger\end{array}$ & $\begin{array}{l}51-58 \\
\text { mature }\end{array}$ & $\begin{array}{l}81-88 \\
\text { mature }\end{array}$ \\
\hline Pair 4: 1974 (1); 1976 (2) & $\begin{array}{c}31-133 \\
\text { young/old }\end{array}$ & $\begin{array}{c}58-160 \\
\text { mature/old }\end{array}$ & $\begin{array}{l}15-17 \\
\text { young }\end{array}$ \\
\hline
\end{tabular}

* Stand origin dates are based on stand origin maps of Heinselman, one of which was published (Heinselman 1973); the others remain unpublished.

+ For convenience, stand ages are grouped into the following age categories: Young (0-40 yr); mature (41-100 yr); old $(101-150 \mathrm{yr})$, and very old $(>150 \mathrm{yr})$.

sociation between pairs of tree species. With categorical data, a standard normal deviate (SND) is obtained for each distance class, which indicates the strength of clustering within one species. An SND of $>2.0$ indicates clustering significant at about the 95\% level, SNDs $<-2.0$ indicate a regular spatial pattern, and SNDs between -2.0 and 2.0 indicate no clustering significant at the $95 \%$ level. Positive spatial clustering at a given distance class $i$ means that one is more likely to encounter individuals of species $B$ at $i \mathrm{~m}$ away from species $A$ than would be the case under a random spatial mixture of species $A$ and $B$. The same assumptions made for Moran's I also apply. Correlograms showing SNDs by distance class were constructed for canopy trees (those receiving direct sunlight) of several dominant species on each plot by $10-\mathrm{m}$ distance classes and understory trees of the same species by $5-\mathrm{m}$ distance classes. Associations between large dead trees $(>15$ $\mathrm{cm} \mathrm{dbh})$ and small live trees $(<5 \mathrm{~cm}$ dbh) were checked (95\% significance level, $0-5 \mathrm{~m}$ distance class) for all species pairs among the dominant species, to see whether there are any patterns of replacement among species.

Patch pattern analysis.-The stem maps were entered into an ARC-INFO Geographical Information System (GIS). The GIS formed a growing-space or Tiesen polygon around each canopy tree, using the perpendicular bisectors of line segments from the subject tree to each of the nearest neighbors. The resulting polygons were then merged wherever two polygons of the same species shared a side, resulting in a map of patches occupied by canopy trees of each species. In some cases, where a canopy tree of one species was completely surrounded by other species, a "patch" consisted of one tree. Thus, there is no arbitrarily set lower limit to patch size. The patch structure maps were then further analyzed using the GIS. Mean patch size and patch size distribution were calculated for each species. Generally, patch sizes are $<0.25$ ha, so that this analysis looked at smaller spatial scales than the air photo analysis.

\section{Ground study sites}

Tree replacement in 'gaps."'-We tallied canopy trees along transects across the study sites (including the embedded permanent mapped plot) that had died during the last $\approx 10$ years. No attempt was made to measure gap area (sensu Runkle 1981, 1982) because there are no gap edges in these forests. The whole forest is laced with a network of interconnected small openings. Instead of measuring regeneration in "gaps," we tallied all live stems within $3 \mathrm{~m}$ of each dead canopy tree in the following categories: $<50 \mathrm{~cm}$ tall, $50-100$ $\mathrm{cm}$ tall, $>100 \mathrm{~cm}$ tall but $<2.5 \mathrm{~cm} \mathrm{dbh}$, and $>2.5 \mathrm{~cm}$ $\mathrm{dbh}$, in which case the dbh was recorded. If one tree had obviously replaced the dead tree in the canopy (e.g., it was much larger than and overtopping all other stems) then that tree was so noted. Otherwise, the species of the largest tree with measured dbh, or, if there were no trees $>2.5 \mathrm{~cm}$ dbh, the species of tree with the largest number of stems in the largest size category present within $3 \mathrm{~m}$ of the dead canopy tree was considered the replacement species. A transition matrix was constructed from this data separately for each of the two study sites.

\section{Air photo study sites}

Air photo interpretation.-Stands that originated during eight different fire years, ranging from 1801 to 1976, are present within a few kilometres of Seagull Lake (Table 1, based on Heinselman 1973). The stand ages are distributed in such a way as to easily group into four pairs which today correspond to young, mature, old, and very old forests (in this region average tree longevity is about a century). One to three air photo study sites were chosen in contiguous, upland stands of each of the eight stand origin dates (total of 15 air photo study sites). Each such site is square and 16 ha 
Solid Matrix

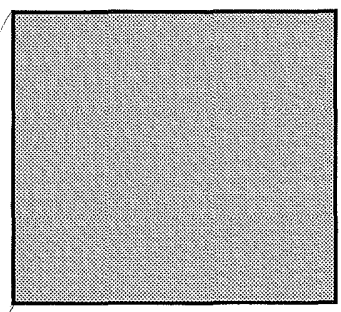

Mosaic

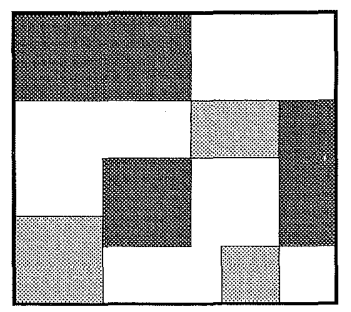

Matrix With Inclusions

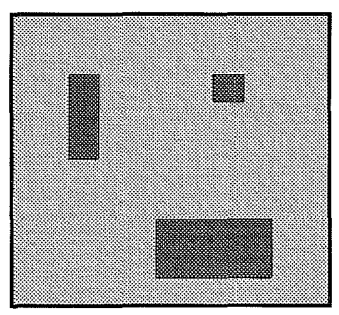

Mixture

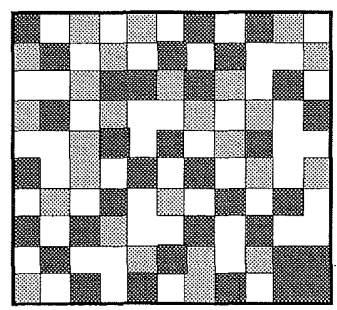

FIG. 2. Examples of spatial structure types: solid matrix (MAS), matrix with inclusions (MAI), mosaic (MOS), and mixture (MIX).

in area, which was the largest area possible without including wetlands, large rock outcrops, parts of stands with other origin dates, or other anomalies. The 1854 and 1974 burned areas were too small for more than one air photo study site. About $25 \%$ of one of the 1903 air photo study sites was submerged, but the remaining area was analyzed.

To facilitate analyses of forest spatial structure, the 15 16-ha study sites were analyzed at three spatial scales (or block sizes): 16 ha ( 14 blocks), 4 ha ( 58 total blocks), and 1 ha (236 total blocks). Clear acetate overlays with the blocks outlined at each of the three block sizes were overlaid on the air photos. The 1934, 1961, and 1991 photo series were taken from different altitudes, and consequently have different scales. Therefore, a zoom transfer scope was used to produce identical alignment of each 16-ha photo study site on each series of photos. The scale of the air photos ranged from 1:16000 to 1:20 000. All photos were cloud-free and of sufficient quality to determine tree species for clumps of trees ( $>0.1$ ha in area). Stereo coverage was available for all of the 1991 photo series, but only partially available for the 1934 and 1961 series.

Interpretation proceeded by classifying each block $(1,4$, or 16 ha) on all three air photos into one of the following four spatial structures (Fig. 2):

1) Solid Matrix (MAS). Block is nearly completely dominated by one species (makes up $>90 \%$ of tree cover).

2) Matrix with Inclusions (MAI). One mono-specific patch comprises at least $50 \%$ of the area.

3) Mosaic (MOS). The block has mono-specific patches ( $>0.25$ ha in area) of two or more species. No one patch comprises $\geq 50 \%$ of the tree cover; however, one species may occupy more than one patch, and may comprise $>50 \%$ of cover.

4) Mixture (MIX). The block has more than one species, but patches of area $>0.25$ ha comprise $<10 \%$ of the area. Thus, the species form a diffuse mixture.

This series of definitions led to the following decision tree used during air photo analysis:

I. The block is solidly occupied by one species ( $>90 \%$ of tree cover).

- Record block as MAS and note the species.

II. The block is not solidly occupied by one species.

A. One mono-specific patch comprises $>50 \%$ (but $<90 \%$ ) of tree cover.

- Record block as MAI and note both matrix and inclusion species.

B. Largest mono-specific patch comprises $\leq 50 \%$ of area.

1. Block mostly ( $>50 \%$ of tree cover) composed of mono-specific patches $>0.25$ ha in area.

- Record block as MOS and note the species present.

2. Block mostly composed of a diffuse mixture of species.

- Record block as MIX and note the species present.

The above classification leads to a simple quantification of the texture, or spatial structure, of the forest at each study site. This type of analysis was decided upon after initial experimentation with the air photos showed that outlining mono-dominant patches was nearly impossible. The "patches" at the landscape level are really intergrading, so that the whole landscape is a continuous network of stands with various mixtures of species. No satisfactory scheme for typing and outlining patches could be devised. The quantification of overall texture at spatial scales from 1 to 16 ha has the advantages of greater objectivity and data that are statistically testable. The proportion of blocks at each spatial scale that are in each of the spatial-structure categories can be directly compared among stands of different age and among dates for the same stand. The one subjective judgement made is what constitutes a mixture versus a group of small patches, which depends on the level of resolution of the photos. For the air photo analysis, a patch was arbitrarily chosen to be of area $\geq 0.25$ ha, a size which is clearly visible. Spatial patterns of even smaller patches were analyzed on the permanent mapped plots, where the spatial scale of the data was much finer. Interpretation of the air photo study sites was backed up by field observation of the authors, US Forest Service cover type maps, and the ground study sites.

One final air photo analysis was completed to look at the effect of stand age at the time of burn on the resulting species composition after the burn. The 1976 fire burned stands that were 73,161 , and 175 years old, 
TABLE 2. Tree species composition and characteristics of the Threemile Island (area $=0.53 \mathrm{ha}$ ) and Fishook Island (area $=0.56 \mathrm{ha}$ ) permanent mapped plots.

\begin{tabular}{|c|c|c|c|c|}
\hline \multirow[b]{2}{*}{ Species } & \multicolumn{4}{|c|}{ Characteristic } \\
\hline & $\begin{array}{c}\text { Basal } \\
\text { area } \\
\left(\mathrm{m}^{2}\right)\end{array}$ & $\begin{array}{c}\text { No. live } \\
\text { stems }> \\
10 \mathrm{~cm} \\
\text { dbh }\end{array}$ & $\begin{array}{c}\text { No. snags } \\
+\operatorname{logs} * \\
>10 \mathrm{~cm} \\
\text { dbh }\end{array}$ & $\begin{array}{l}\text { No. live } \\
\text { stems }> \\
10 \mathrm{~cm} \mathrm{dbh}\end{array}$ \\
\hline \multicolumn{5}{|c|}{ Threemile Island Plot } \\
\hline Red pine & 5.93 & 72 & $(85) \dagger$ & 1 \\
\hline Jack pine & 0.59 & 8 & $(45) \dagger$ & 0 \\
\hline Black spruce & 0.70 & 24 & 52 & 96 \\
\hline Balsam fir & 1.73 & 97 & 205 & 903 \\
\hline White cedar & 2.61 & 78 & 36 & 132 \\
\hline Paper birch & 1.12 & 46 & 12 & 133 \\
\hline Other & 0.18 & 4 & 0 & 74 \\
\hline Total & 12.86 & 329 & 435 & 1339 \\
\hline \multicolumn{5}{|c|}{ Fishook Island Plot } \\
\hline Jack pine & 3.71 & 65 & 119 & 1 \\
\hline Black spruce & 4.17 & 151 & 147 & 374 \\
\hline Paper birch & 2.10 & 84 & 17 & 166 \\
\hline Other & 0.11 & 9 & 25 & 10 \\
\hline Total & 10.09 & $\cdot 309$ & 308 & 551 \\
\hline
\end{tabular}

* Snags + logs includes full tally of all standing dead and snagged trees plus estimated number of logs on each plot, based on a tally of logs on $18 \%$ of the Threemile Island plot and $16 \%$ of the Fishook Island plot.

$\dagger$ Species identification of logs for red and jack pine is not always reliable. However, of the total of 130 pine logs and standing dead trees, $\approx 85$ and 45 were red and jack pine, respectively.

since they had previously burned in 1903,1815 , and 1801, respectively (Fig. 1). We overlaid a dot grid on the parts of the 1801,1815 , and 1903 stands that reburned in 1976, and counted each dot as falling in aspen or jack pine covertype. The result is an estimate of the proportion of the 15-yr-old forest (as of 1991) in each of the two covertypes as a function of age at the time of burn in 1976.

\section{RESUlts}

\section{Permanent mapped plots and ground study sites}

Age, size structure, and stand development at Threemile Island.-The Threemile Island mapped plot is currently occupied by an old multi-aged stand. There are substantial remnants of a red pine cohort originating from the 1801 fire, which although low in stem number $(\approx 20 \%$ of trees $>10 \mathrm{~cm} \mathrm{dbh}$ ), have nearly half of the plot basal area (Table 2). White cedar, balsam fir, paper birch, black spruce, and jack pine combined make up $\approx 50 \%$ of the basal area and $80 \%$ of trees $>10 \mathrm{~cm} \mathrm{dbh}$. Balsam fir dominates the small tree size class $(<10 \mathrm{~cm}$ dbh; Table 2), making up two-thirds of the population, while paper birch, white cedar, and black spruce each make up $\approx 10 \%$ of the population, and red/jack pine are virtually nonexistent (Fig. 3).

The red pine cohort of post-1801 origin exhibits a unimodal age distribution between 1805 and 1830, centered $\approx 1815$. There was also a substantial amount of jack pine in the original stand, as evidenced by the presence of both standing dead and downed jack pine. Although the current ratio of living red : jack pine $\geq 10$ $\mathrm{cm} \mathrm{dbh}$ is $9: 1$, the ratio of living plus dead trees and $\operatorname{logs} \geq 10 \mathrm{~cm}$ dbh is only $3: 1$. Jack pine is known to be shorter lived than red pine, so it makes sense that only a few live jack pine remain. One complete core was obtained from a jack pine (the majority of which are hollow) and it dates from the same time as the original red pine cohort. None of the trees in the 18051830 pine cohort showed evidence of release at that time; at $1.0 \mathrm{~m}$ height, all showed rapid early growth or a declining pattern typical of trees in an even-aged stand. The stand then entered a relatively stable period from 1830 to 1890 , during which new canopy recruitment was minimal (Fig. 4). Ring widths of the red pines during this period were generally narrow (Fig. 5), with periods of $\geq 20$ years with ring widths $<1.0 \mathrm{~mm}$ on 26 of 28 trees and $<0.5 \mathrm{~mm}$ on 17 of 28 trees. These narrow ring widths indicate intense competition and self-thinning until canopy-opening disturbance(s) during the 1890 decade. At that point, the stand was old enough that some trees would have been large enough to be vulnerable to windthrow. The disturbance was likely wind because most of the surviving trees that were released were only $4-12 \mathrm{~cm}$ dbh at the time of release. Fire would have killed trees that small, while only scarring the larger trees. It is difficult to imagine a fire that would kill the large trees but not the small ones-only wind does that. In addition, there are no fire scars on the surviving red pine. Red pine is known to retain visible and datable fire scars for at least a century (Frissell 1973, Heinselman 1973). Red pine canopy recruitment after 1830 was generally by release from suppression when other trees in the neighborhood died. Only 2 of 30 red pines cored were distinctly younger than the post-1801 fire cohort. These two trees were recruited into the canopy during the 1850 and 1870 decades.

After 1890, episodic canopy disturbance became quite common in the Threemile Island mapped plot, and species other than red pine began to fill the canopy. Currently, $46 \%$ of the basal area among canopy trees is in red pine (Table 2), and the original red pine cohort only occupies $\approx 22 \%$ of the canopy area (Fig. 4). Because 1890 was the last decade with substantial red pine canopy recruitment, the period starting after that (1900-1990) was used to examine recruitment of the four replacement species. The $y$-axis in Fig. 4 represents percentage of current canopy area recruited during a given decade; summing these percentages for all decades from 1900-1990 shows that during this period, three of the species (balsam fir, white cedar, and paper birch) had similar areas of canopy recruitment, and black spruce had about one-half the area of the other three. Rapid early growth is exhibited by a large majority of individual canopy recruits of shade-tolerant species like black spruce (92\%), balsam fir $(95 \%)$, and white cedar $(61 \%)$, and also the shade-intolerant spe- 

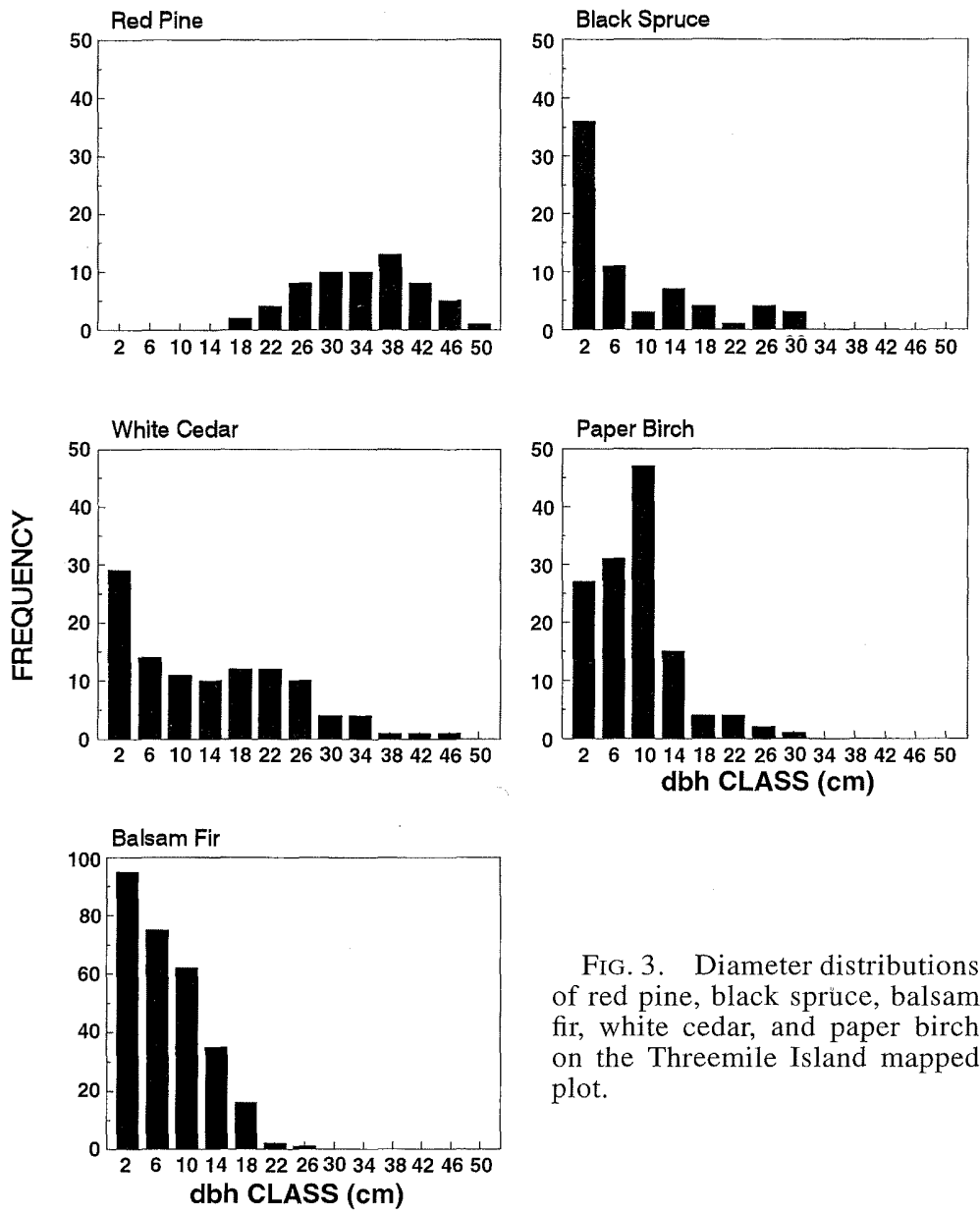

FIG. 3. Diameter distributions of red pine, black sprüce, balsam fir, white cedar, and paper birch on the Threemile Island mapped plot.

cies paper birch $(80 \%)$. Such rapid early growth indicates recruitment directly into gaps (likely in paper birch), or the existence of small advance regeneration $(<1 \mathrm{~m}$ height) that established in the understory (likely in the shade-tolerant species).

Age, size structure, and stand development at Fishook Island.-The same fire of 1801 that burned the Threemile Island mapped plot and much of the surrounding area also apparently burned much of Fishook Island. Evidence for this is a few very old remnant jack pine trees on the mapped plot (Fig. 4), and that the north half of the island is all forest of 1801 origin (M. L. Heinselman, unpublished data). Thus, the 1864 fire that originated the current Fishook stand probably burned in a stand that was only $64 \mathrm{yr}$ old. Today, the forest on the Fishook plot is in early stages of demographic transition from even-aged to old multi-aged. There is still one very dominant cohort that originated after the 1864 fire, with peak recruitment of the three major species-jack pine, black spruce and paper birch-during the 1885 decade (Fig. 4). As with the Threemile Island stand, it apparently took three decades for trees to fully stock the stand. This length of time is common on rocky areas, where soils are shal- low, mainly organic, and are often burned off during fires. At present, young cohorts occupy a relatively small area, which is nearly all dominated by black spruce and paper birch. There has been no new jack pine canopy recruitment since 1900 . During the last 5$10 \mathrm{yr}$ much of the canopy has broken up, so that there are many logs on the forest floor (Table 2). Much of the canopy breakup occurred during a heavy snowstorm in October 1990 (L. E. Frelich, personal observation). Prior to canopy breakup, there were at least twice the number of live trees $>10 \mathrm{~cm}$ dbh as there are at this time (Table 2). When all of the downed logs and dead trees were alive, the tree count on the plot was 617 trees and density was 1046 trees/ha, within the range of 800-1600 trees/ha reported by Heinselman (1973) for comparably aged stands.

The very recent canopy openings on the Fishook mapped plot are now rapidly being filled with black spruce and paper birch recruitment, including both new seedlings and released saplings. Balsam fir and white cedar are just beginning to appear in the canopy of the Fishook Island forest at a stand age of $129 \mathrm{yr}$, with three live individuals $>10 \mathrm{~cm}$ dbh of each species. By contrast, the 193-yr-old Threemile Island stand has 97 
Three Mile Island

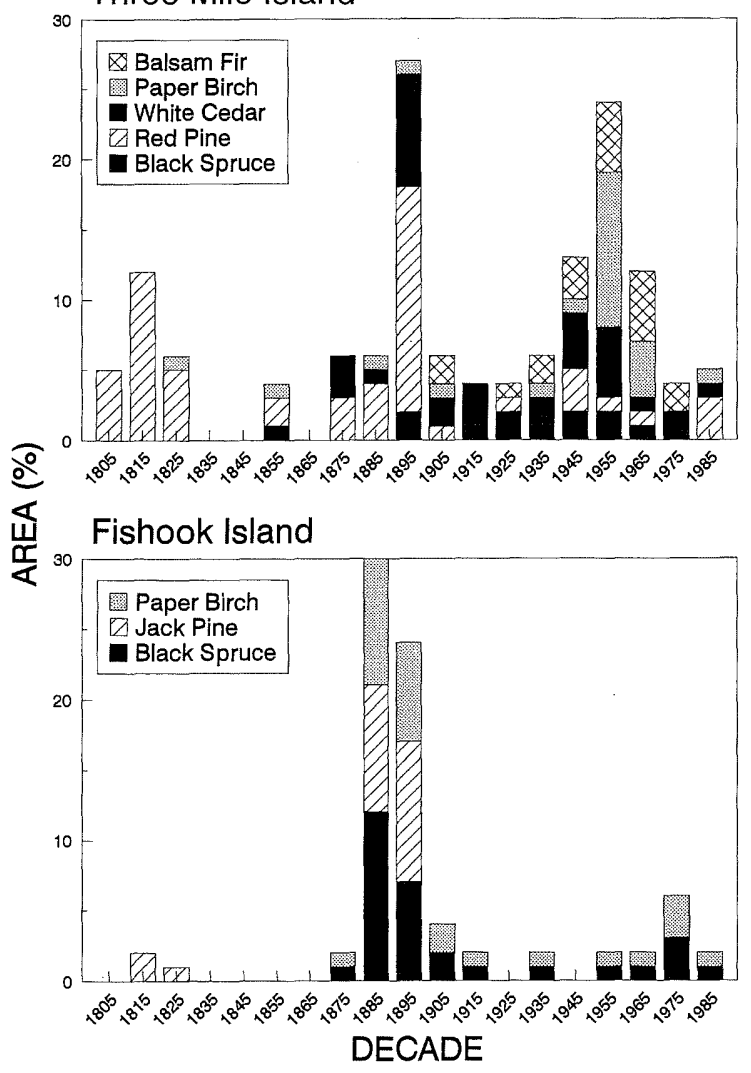

FIG. 4. Canopy disturbance chronologies for Threemile Island and Fishook Island permanent mapped plots. $y$-axis shows the percentage of plot area occupied by canopy trees of each species and the $x$-axis shows decades during which canopy accession took place.

and 78 live stems $>10 \mathrm{~cm}$ dbh of balsam fir and white cedar, respectively. Small trees $(<10 \mathrm{~cm} d b h)$ also show a similar contrast in abundance (Table 2 ).

The Fishook disturbance chronology (Fig. 4) represents 111 canopy accession events, of which only 6 are releases from suppression. As with Threemile Island, nearly all recently recruited trees show rapid early growth and an arch-shaped or slowly declining growth pattern typical of recruitment directly into a gap (or prior existence of young, small seedlings $<1 \mathrm{~m}$ in height), rather than establishment on the forest floor, prolonged growth and survival as advanced regeneration under suppression, then release into a canopy gap. Because the Fishook stand is relatively young, there are too few cores from trees in the post-breakup age class to analyze the proportion of area filling with each species on the disturbance chronology. However, this issue is addressed under transition probabilities.

Spatial patterns among overstory trees.-Overstory trees at both Threemile Island and Fishook Island are highly clustered. Spatial autocorrelation is significant for all of the leading dominant species on both plots at distances ranging from $5 \mathrm{~m}$ for black spruce at Fish-

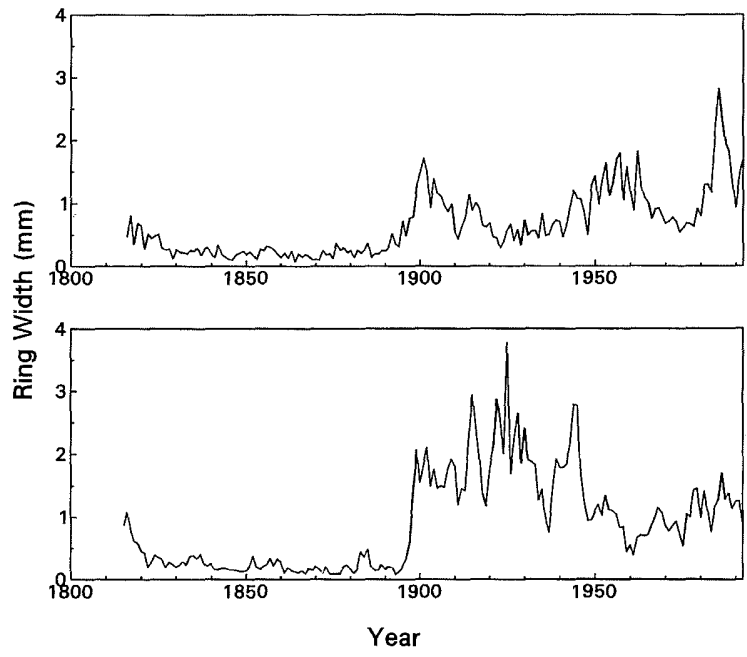

FIG. 5. Radial increment patterns for two representative red pines $(n=30)$ from the Threemile Island permanent mapped plot. Note the peak in radial growth shortly after 1801 , the year of origin, followed by a decline with very slow radial growth for several decades, followed by a large abrupt increase $\approx 1895$.

ook Island to $25 \mathrm{~m}$ for paper birch on Threemile Island (Table 3). The significant autocorrelation is reinforced by visual inspection of the patch maps (Fig. 6) and associated statistics (Table 4). The mean mono-specific patch sizes of 35 and $82 \mathrm{~m}^{2}$, for the Threemile Island and Fishook mapped plots, respectively, are several times mean tree crown size of 5-10 $\mathrm{m}^{2}$, indicating that a patch of average area comprises several to many adjacent trees of the same species. Except for balsam fir and white cedar on Fishook Island, which are just be-

TABLE 3. Maximum distance of significant (95\%) association among conspecific trees on the Threemile Island and Fishook Island mapped plots. Symbol " 0 " indicates no significant association at any distance class. Significance was determined by spatial autocorrelation standard normal deviates. Blank indicates that the number of trees was too low to calculate association. In addition, age at Threemile Island is correlated to $30 \mathrm{~m}$.

\begin{tabular}{|c|c|c|c|}
\hline \multirow[b]{2}{*}{ Species } & \multicolumn{3}{|c|}{ Type of association } \\
\hline & $\begin{array}{l}\text { Overstory- } \\
\text { overstory }\end{array}$ & $\begin{array}{l}\text { Understory- } \\
\text { overstory }\end{array}$ & $\begin{array}{l}\text { Live gap } \\
\text { trees } \leq 5 \mathrm{~cm} \\
\text { dbh }\end{array}$ \\
\hline \multicolumn{4}{|c|}{$\begin{array}{l}\text { Threemile Island } \\
\text { Distance (m) }\end{array}$} \\
\hline Red pine & 15 & & \\
\hline Black spruce & 10 & 5 & 5 \\
\hline Paper birch & 25 & 5 & 10 \\
\hline Balsam fir & 15 & 15 & 5 \\
\hline White cedar & 10 & 5 & 10 \\
\hline \multicolumn{4}{|c|}{$\begin{array}{l}\text { Fishook Island } \\
\qquad \text { Distance (m) }\end{array}$} \\
\hline Jack pine & 20 & & \\
\hline Black spruce & 5 & 10 & 0 \\
\hline Paper birch & 10 & 0 & 10 \\
\hline
\end{tabular}


Fig. 6. Patch maps of the Threemile Island and Fishook Island permanent mapped plots.
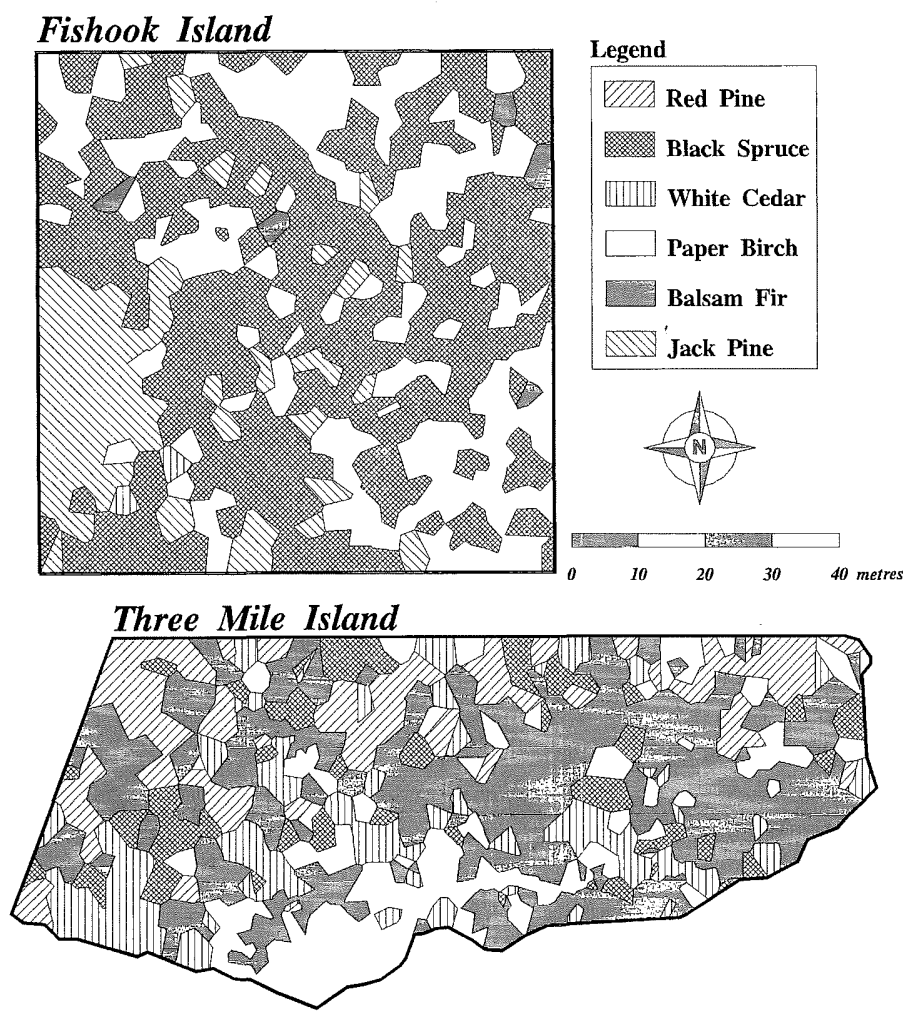

ginning to invade at the canopy level and have few individuals, the number of patches among species ranges from 17 to 37 . The largest five of these patches comprise $49-100 \%$ of the total area occupied by each species, and the largest patch comprises $20-75 \%$ of the area occupied by each species (Table 4 ). It should be noted that in this analysis, patches must be contiguous but not necessarily homogeneous (i.e., they may contain smaller patches within) and may have complex shapes rather than circular or blocky shapes. At the same time, the median patch size is quite small. Thus, the overall spatial pattern is one of a few large patches that occupy most of the area, with many small scattered patches composed of one to several trees (Fig. 6).

The major difference between the Threemile Island and Fishook plots is in the number, size, and composition of patches. The mean and median mono-specific patch sizes, and the size of the largest mono-specific patch are (with the white cedar and balsam fir exception noted above) larger at the younger Fishook Island plot.

TABle 4. Patch statistics for the Threemile Island and Fishook Island mapped plots. These statistics correspond to the patches visible in Fig. 6.

\begin{tabular}{|c|c|c|c|c|c|c|}
\hline \multirow[b]{2}{*}{ Species } & \multirow[b]{2}{*}{$\begin{array}{c}\text { Number of } \\
\text { patches }\end{array}$} & \multirow[b]{2}{*}{$\begin{array}{l}\text { Median patch } \\
\text { area }\left(\mathrm{m}^{2}\right)\end{array}$} & \multirow[b]{2}{*}{$\begin{array}{l}\text { Mean patch } \\
\text { area }\left(\mathrm{m}^{2}\right)\end{array}$} & \multirow[b]{2}{*}{$\begin{array}{c}\text { Area of largest } \\
\text { patch }\left(\mathrm{m}^{2}\right)\end{array}$} & \multicolumn{2}{|c|}{ Area in: } \\
\hline & & & & & $\begin{array}{c}\text { largest } \\
\text { patch }\end{array}$ & $\begin{array}{l}\text { largest five } \\
\text { patches } \\
(\%) \text { }\end{array}$ \\
\hline \multicolumn{7}{|c|}{ Threemile Island } \\
\hline $\mathrm{A} 11^{*}$ & 150 & 11.0 & 35.1 & 1129.9 & 21.4 & 41.8 \\
\hline Black spruce & 33 & 8.9 & 15.7 & 103.9 & 20.0 & 48.6 \\
\hline Red pine & 20 & 15.6 & 42.7 & 237.4 & 27.8 & 73.3 \\
\hline White cedar & 37 & 9.9 & 21.9 & 191.6 & 23.6 & 61.1 \\
\hline Paper birch & 33 & 11.6 & 28.4 & 505.9 & 54.1 & 70.1 \\
\hline - Balsam fir & 27 & 13.4 & 79.7 & 1129.9 & " 52.5 & 74.7 \\
\hline \multicolumn{7}{|c|}{ Fishook Island } \\
\hline All* & 72 & 15.8 & 82.4 & 2327.9 & 39.3 & 67.5 \\
\hline Black spruce & 17 & 27.4 & 181.4 & 2327.9 & 75.5 & 92.7 \\
\hline Jack pine & 19 & 15.9 & 47.0 & 569.3 & 63.7 & 78.0 \\
\hline -White cedar & 2 & 14.6 & 14.6 & 15.7 & 53.7 & 100.0 \\
\hline Paper birch & 29 & 15.4 & 63.6 & 555.2 & 30.1 & 73.3 \\
\hline Balsam fir & 5 & 15.1 & 15.5 & 23.3 & 30.1 & 100.0 \\
\hline
\end{tabular}

* All species pooled rather than all species averaged. 
TABLE 5. Association between live and dead trees in the 0-5 $\mathrm{m}$ distance class for the Threemile Island and Fishook permanent mapped plots. The symbols,+ 0 , and - indicate positive, neutral, and negative spatial associations, respectively. Positive and negative associations shown are significant at $95 \%$ as determined by spatial autocorrelation standard normal deviates. Blanks indicate that the number of trees was too low to calculate association. Large dead trees are $>15 \mathrm{~cm}$ dbh, and $\mathrm{small}$ live trees are $\leq 5 \mathrm{~cm}$ dbh.

\begin{tabular}{|c|c|c|c|c|c|c|}
\hline \multirow{2}{*}{$\begin{array}{c}\text { Species of small } \\
\text { live tree }\end{array}$} & \multicolumn{6}{|c|}{ Species of large dead tree } \\
\hline & Jack pine & Red pine & Black spruce & Paper birch & Balsam fir & White cedar \\
\hline \multicolumn{7}{|c|}{ Threemile Island } \\
\hline Black spruce & & - & 0 & 0 & 0 & 0 \\
\hline Paper birch & & 0 & 0 & 0 & 0 & 0 \\
\hline Balsam fir & & - & - & 0 & - & 0 \\
\hline White cedar & & 0 & 0 & - & - & 0 \\
\hline \multicolumn{7}{|c|}{ Fishook Island } \\
\hline Black spruce & 0 & & - & 0 & & \\
\hline Paper birch & - & & - & - & & \\
\hline
\end{tabular}

The forest on this plot is just now moving from the original spatial structure of matrix with inclusions, rapidly through a mosaic phase and into a mixture. The process is not complete, and remnants of large patches that were part of the original postfire cohort (that now occupy $55 \%$ of the canopy area; Fig. 4), are still in place. In contrast, the original cohort at Threemile Island only occupies $\approx 22 \%$ of the canopy area. Therefore, the breakup of the Threemile stand has proceeded further, allowing the formation of many smaller patches of invading species. In addition, balsam fir and white cedar have made much larger inroads into the Threemile Island stand, so that four dominant species share space to a greater extent, leading to a higher probability that trees of a given species will be adjacent to a different species. This results in smaller patches. Paper birch and black spruce at Fishook Island are the only two abundant species that are capable of maintaining themselves in older forests at this time, thus their patch sizes are substantially larger.

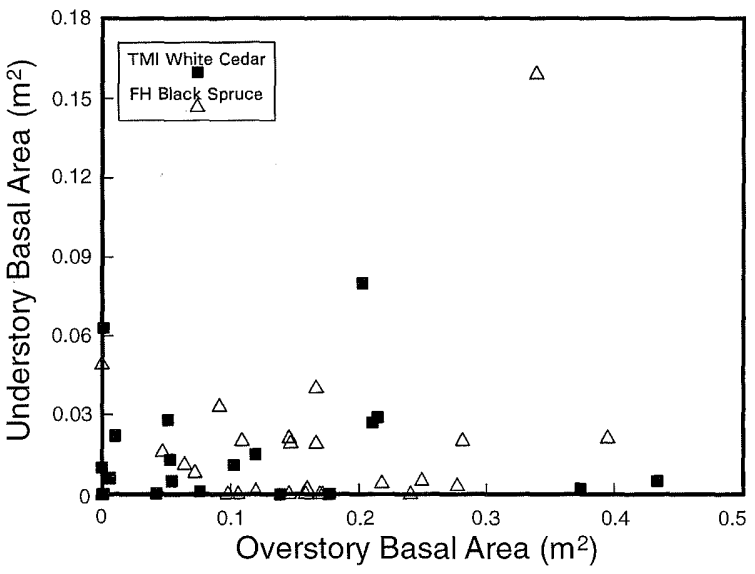

FIG. 7. Examples of overstory-understory abundance relationships on the mapped plots: white cedar on Threemile Island (TMI) and black spruce on Fishook Island (FH). Each symbol represents one $15 \times 15 \mathrm{~m}$ subplot $(n=23$ on TMI and 25 on $\mathrm{FH}$ ). Understory trees are those that receive no direct sunlight from above, and are generally $2-6 \mathrm{~cm}$ dbh on these plots.
Spatial patterns of mortality and replacement.Mortality to canopy trees occurs in randomly scattered groups from 10 to $30 \mathrm{~m}$ across, caused by windthrow or, in the case of balsam fir on Threemile Island, by spruce budworm attack (L. E. Frelich, personal observation). No species of small live tree has a positive association with any species of large dead tree on either plot (Table 5). The spatial associations are mostly neutral, indicating that species-by-species replacement is random, although this randomness does not imply that the area or proportion of gaps invaded should be equal among species. A few associations are negative, and these mostly occur under conifers casting dense shade where the overall abundance of small live trees would not be great before a given large tree died. If some of the large trees died recently, there may not have been time for many new seedlings to invade the location.

Once trees are released into or invade gaps, they do so in small mono-dominant patches. Small live gap trees $(\leq 5 \mathrm{~cm} \mathrm{dbh}$ ), with the exception of black spruce on Fishook Island, are in tight clusters $5-10 \mathrm{~m}$ in diameter (Table 3). Different species can fill adjacent canopy openings, or two species may each fill part of one larger opening. In any case, there is separation of gap-invading species into patches.

Understory trees are also clustered in $5-15 \mathrm{~m}$ diameter patches (Table 3). The dominance (as measured by basal area) of a given species in the understory is not quantitatively related to the species composition of the overstory on $15 \times 15 \mathrm{~m}$ subplots within the two mapped plots (Fig. 7). For every pair of species (with one exception), the overstory-understory relationship had no significant slope, the data were all clustered along zero on the $y$-axis, or no model could be found that fit the data. The exception was balsam fir understory versus paper birch overstory on Threemile Island, where there was a significant $(P=0.024)$ positive slope for a simple linear regression with an appropriate residual pattern. Because the Threemile Island plot has a generally dense coniferous canopy, it is not surprising that balsam fir abundance in the understory would be higher in neighborhoods with more paper birch in the 
canopy, since light levels would be higher there, and the chance would be greater that a balsam fir sapling would survive to $1.4 \mathrm{~m}$ in height (the minimum for mapping in this study).

Moran's I for tree age (continuous variable) on Threemile Island indicates age contagion significant at the $95 \%$ level for distances $\leq 20 \mathrm{~m}$. This size of patch also matches well with the size of species patches for canopy trees. For example, four mono-specific clusters of trees that entered the canopy during the 1950-1959 decade were detected among the 109 trees cored. The size and species composition of these clusters (not shown) agrees with the patch size indicated by spatial autocorrelation analyses for canopy trees and tree age. A similar analysis of age was not done for the younger forest on Fishook Island, because most of the trees still date from the time of the stand-originating fire, and young trees invading canopy openings are not yet large enough to core.

Figs. 8 and 9 demonstrate the patterns indicated by the spatial statistics and how the replacement process works in upland forests of the Seagull Lake area. In the case of balsam fir on Threemile Island (Fig. 8), clusters of small trees in gaps are spatially separated from the major concentrations of both dead balsam fir and live canopy balsam fir. Thus, balsam fir is replacing itself on the plot, but in different locations than the current large trees. Paper birch and black spruce on Fishook Island (Fig. 9) illustrate how small gap trees of each species occur in dense clumps that are spatially separated. As with balsam fir on Threemile Island, the major clusters of young gap trees of each species are not necessarily close to major concentrations of large conspecific canopy trees.

Transition probabilities.-No transitions to pine were observed on either ground study area. A dying pine on Threemile Island has an $\approx 33 \%$ chance of replacement by paper birch, an $\approx 30 \%$ chance of replacement by black spruce, and an $\approx 20 \%$ chance of replacement by each balsam fir and white cedar (Table 6 ). On Fishook Island, dying pines have an $\approx 60 \%$ and $\approx 30 \%$ chance of being replaced by black spruce or paper birch, respectively. Transition probabilities from black spruce to the other species are not markedly different from those just cited for pine on either ground study site. The strongest tendency for self replacement is for white cedar on Threemile Island, although the sample size is quite small. Of the other species at Threemile Island, balsam fir, black spruce, and paper birch are about equally likely to replace themselves. Balsam fir is more likely to replace paper birch than any other species, which is consistent with our finding that balsam fir understory trees have a significant quantitative relationship to overstory paper birch.

Transition probabilities for all species at Threemile Island range only from 24 to $29 \%$ among black spruce, balsam fir, and paper birch, while white cedar is lower than the others at $\approx 19 \%$ (Table 6 ). In the younger Fish-
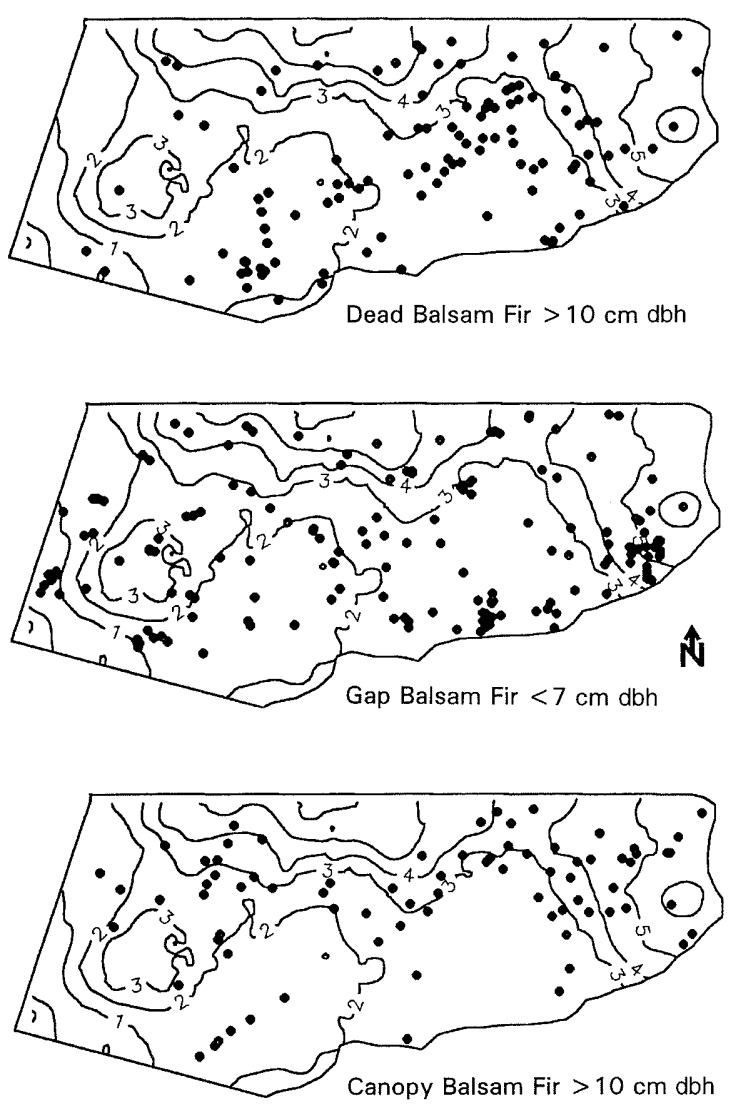

FIG. 8. Independence among conspecific small trees in gaps, large canopy trees, and large dead trees. Example: balsam fir on the Threemile Island permanent mapped plot. Contours show elevation in $\mathrm{m}$, starting from the lowest point on the plot. Total east to west length of the plot is $126 \mathrm{~m}$. Note the locations of concentrations of small balsam fir in gaps. Balsam fir in gaps are generally not replacing dead balsam fir in the same location, and are not restricted to areas nearby large canopy balsam fir.

ook Island forest, transition probabilities from all species are similar to those for pine alone or black spruce alone. This may change in the future, however, as balsam fir and white cedar continue to make inroads into the stand.

\section{Air photo study sites}

Succession and species composition.-All young ( $<40 \mathrm{yr}$ old ) blocks of forest examined are dominated by jack pine and/or aspen, sometimes with minor amounts of black spruce or red pine. All very old stands examined are composed of various proportions of black spruce, balsam fir, paper birch, and white cedar, occasionally with a few surviving jack or red pine. All young or mature stands in 1934 that were also present on 1961 and 1991 photos and that did not burn during the 1934-1991 time period proceeded along the successional sequence from jack pine/aspen to some combination of black spruce, balsam fir, paper birch, and white cedar. The previous three statements are true at 


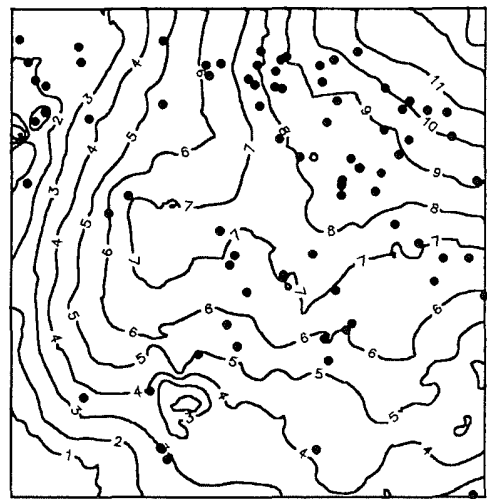

Canopy Paper Birch $>10 \mathrm{~cm}$ dbh

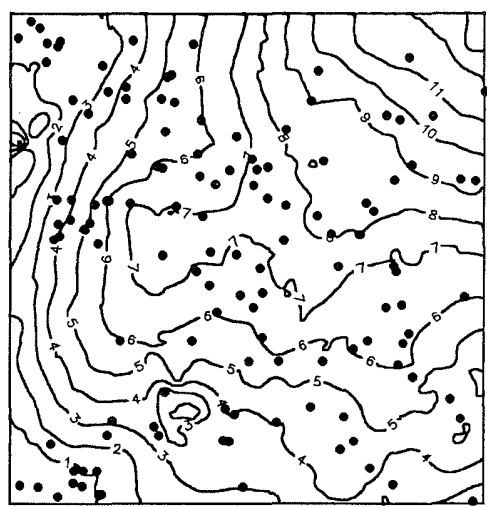

Canopy Black Spruce $>10 \mathrm{~cm}$ dbh

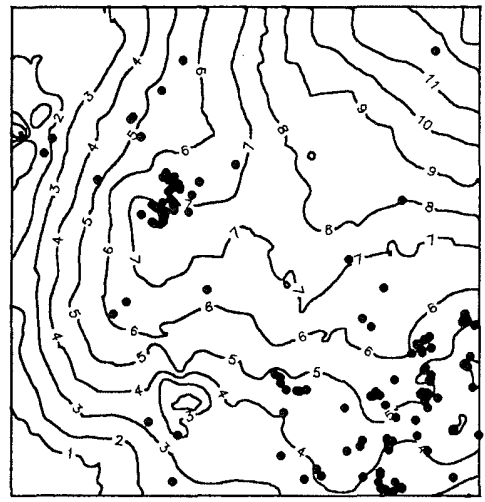

Gap Paper Birch $<5 \mathrm{~cm}$ dbh

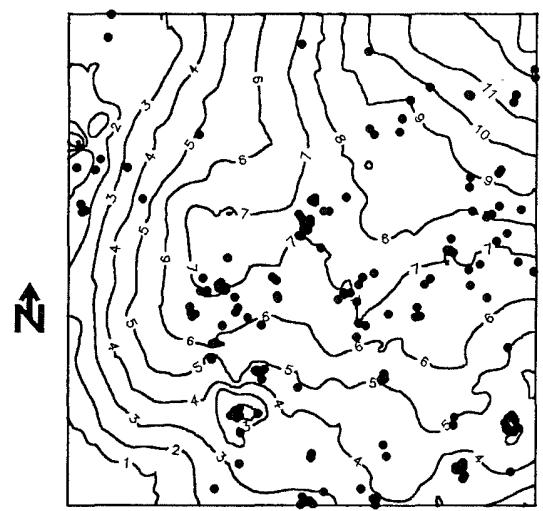

Gap Black Spruce $<5 \mathrm{~cm}$ dbh

FIG. 9. Independence among heterospecific small trees in gaps and large canopy trees. Example: paper birch and black spruce on the Fishook Island permanent mapped plot. Contours show elevation in $\mathrm{m}$, starting from the lowest point on the plot. Total east to west length of the plot is $76 \mathrm{~m}$. Note that the concentrations of small gap paper birch and small gap black spruce are spatially separated.

TABLE 6. Observed transition frequencies for tree replacement on the two ground study sites (which include the permanent mapped plots).

\begin{tabular}{lcccc}
\hline \hline & \multicolumn{4}{c}{ Transition to: } \\
\cline { 2 - 5 } Transition from $(N):$ & Black & Balsam & Paper & White \\
spruce & fir & birch & cedar \\
\hline
\end{tabular}

Threemile Island

Transition frequency
Jack/red pine (77)

Black spruce (43)

Balsam fir (49)

Paper birch (11)

White cedar (12)

All (192)

Jack pine (20)

Black spruce (44)

Paper birch (1)

All (65)

\begin{tabular}{llll}
\multicolumn{5}{c}{ Transition frequency } \\
\hline 0.286 & 0.195 & 0.325 & 0.195 \\
0.326 & 0.209 & 0.349 & 0.116 \\
0.286 & 0.327 & 0.224 & 0.163 \\
0.181 & 0.545 & 0.273 & 0 \\
0.083 & 0 & 0.167 & 0.750 \\
0.276 & 0.240 & 0.292 & 0.193 \\
Fishook Island \\
\multicolumn{5}{c}{ Transition frequency } \\
\hline 0.600 & 0.050 & 0.300 & 0.050 \\
0.610 & 0.023 & 0.364 & 0 \\
0 & 0 & $100.0 *$ & 0 \\
0.600 & 0.031 & 0.354 & 0.015
\end{tabular}

* Not valid due to small sample size. all three spatial scales and all three timepoints (although there were no very old stands present in 1934). This change in species composition parallels that indicated by the diameter distributions (Fig. 3) and stand history reconstructed from tree ring analysis (Fig. 4) in the old-growth forest on Threemile Island, both of which show invasion of the pine stand canopy by the same four species seen on the air photos.

The loss of jack pine over time can be quantified by examining the percentage of 1 -ha blocks with visible jack pine present in 1934 that still have jack pine in 1961 and 1991. For 1-ha blocks that were young in $1934(n=28)$, there is no depletion over time, whereas there is some depletion for stands that were mature in $1934(n=48)$, and a total loss of jack pine by 1991 for stands that were old (100-150 yr old, $n=63$ ) in 1934 (Fig. 10). Thus, once stands reach old age, jack pine is likely to disappear as an important component of a stand within $60 \mathrm{yr}$.

One-hundred percent of 1-ha blocks examined on the 1934 air photos were dominated by jack pine (Fig. 10), 


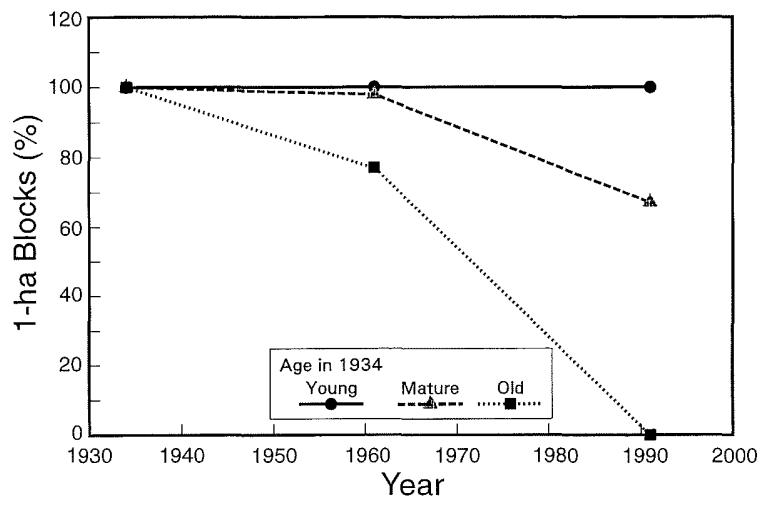

FIG. 10. Percentage of 1-ha blocks with jack pine over time. The same 1-ha blocks were interpreted on air photos from three dates: 1934, 1961, and 1991. The rate of decline in jack pine depends on how old the stand was in 1934. Note that a small number of widely scattered individual jack pines not visible on air photos may occur.

including a variety of young, mature, and old stands. In contrast, only 23 of 321 -ha blocks $(72 \%)$ on the two study sites in the 1976 burn were dominated by jack pine; the remaining $28 \%$ had only aspen as of 1991. A dot-grid count on the 1991 air photo of the entire 1976 burn, where each dot was counted as aspen or jack pine, reveals that $35 \%$ of the burn is now occupied by aspen and $65 \%$ by jack pine (Table 7 ). The percentage occupied varies slightly within the burn depending on the age of the forest at the time of burn in 1976, with 73-yr-old forests returning to a higher percentage jack pine after the burn than 161- or 175-yrold forests (Table 7).

The loss of pine would be stretched out over a longer time for those few stands that start out after a fire with red pine. There are not enough such stands on the air photos for an adequate sample. However, analysis of the Threemile Island mapped plot indicates a significant component of red pine present at age $192 \mathrm{yr}$, and other BWCAW stands 300 yr old still have more than a few scattered red pine (Heinselman 1973).

Succession and spatial structure.-Young stands are predominantly matrices with inclusions (of jack pine with aspen inclusions or vice versa), at 1-, 4-, and 16ha spatial scales (Fig. 11). At the 1- and 4-ha spatial scales, some blocks of forest are solid matrices of jack

TABLE 7. Percentage of area occupied by jack pine and aspen-dominated forest (as of 1991) on the 1976 burn site. Area estimates are based on dot-grid counts on 1991 color infrared air photos. The 1976 fire partly burned forests originated in 1801,1815 , and 1903.

\begin{tabular}{ccc}
\hline \hline \multirow{2}{*}{$\begin{array}{c}\text { Year of origin/age } \\
\text { at time of 1976 } \\
\text { burn (yr) }\end{array}$} & \multicolumn{2}{c}{ Area occupied, 1991: } \\
\cline { 2 - 3 } & & Jack pine \\
\hline $1903 / 73$ & 74.5 & Aspen \\
$1815 / 161$ & 64.3 & 25.5 \\
$1801 / 175$ & 61.9 & 35.7 \\
\hline
\end{tabular}
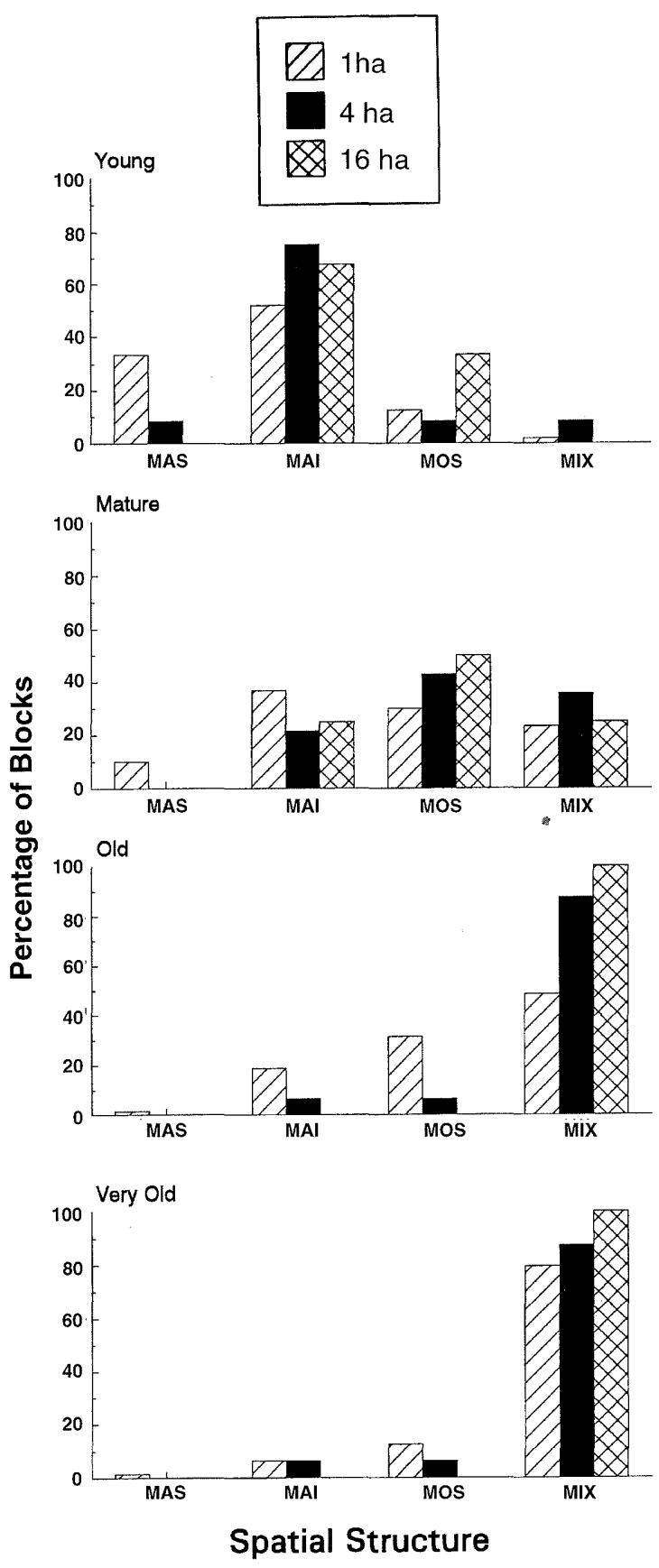

FIG. 11. Spatial structure of 1-, 4-, and 16-ha blocks of forest in 1991. Percentage of blocks that are solid matrices (MAS), matrices with inclusions (MAI), mosaics (MOS), or mixtures (MIX), for stands in young through very old age classes are shown. Based on air photo interpretation of 15 16-ha study sites (see Fig. 1 and Table 1).

pine or aspen. No 16-ha solid matrices were observed for any age class at any date (1934, 1961, or 1991). Mosaics of jack pine and aspen also occur among young stands, especially at the 16-ha scale. Mixtures are rare among young stands. In contrast, in the mature age class, black spruce that were initially present in 
TABLE 8. Observed transition frequencies among spatial structures of 1-ha blocks of forest. Based on analysis of sequential air photos in 1934, 1961, and 1991. Definitions of spatial structures and spatial scales are in Methods, Air photo study sites. Note that there were no very old stands in 1934 or young stands in 1961.

\begin{tabular}{|c|c|c|c|c|c|c|c|c|c|}
\hline \multirow{4}{*}{$\begin{array}{l}\text { Stand age in } \\
1934 \text { or } 1961 \text { : }\end{array}$} & \multirow{4}{*}{$\begin{array}{l}\text { Transition } \\
\text { from: }\end{array}$} & \multicolumn{8}{|c|}{ Transition period } \\
\hline & & \multicolumn{4}{|c|}{$1934-1991$} & \multicolumn{4}{|c|}{$1961-1991$} \\
\hline & & \multicolumn{4}{|c|}{ Transition to: } & \multicolumn{4}{|c|}{ Transition to: } \\
\hline & & MAS* & MAI* & MOS* & MIX* & MAS & MAI & MOS & MIX \\
\hline & & \multicolumn{8}{|c|}{ Transition frequency } \\
\hline Young $\dagger$ & $\begin{array}{l}\text { MAS } \\
\text { MAI } \\
\text { MOS } \\
\text { MIX }\end{array}$ & $\begin{array}{l}0.285 \\
0.090\end{array}$ & $\begin{array}{l}0.429 \\
0.545 \\
0.143 \\
0.333\end{array}$ & $\begin{array}{l}0.364 \\
0.857 \\
0.333\end{array}$ & $\begin{array}{l}0.285 \\
0.333\end{array}$ & & & & \\
\hline Mature $\dagger$ & $\begin{array}{l}\text { MAS } \\
\text { MAI } \\
\text { MOS } \\
\text { MIX }\end{array}$ & 0.125 & $\begin{array}{l}0.200 \\
0.133 \\
0.250 \\
0.250\end{array}$ & $\begin{array}{l}0.133 \\
0.500\end{array}$ & $\begin{array}{l}0.800 \\
0.733 \\
0.250 \\
0.625\end{array}$ & $\begin{array}{l}0.800 \\
0.054 \\
0.029\end{array}$ & $\begin{array}{l}0.514 \\
0.161 \\
0.257\end{array}$ & $\begin{array}{l}0.189 \\
0.484 \\
0.029\end{array}$ & $\begin{array}{l}0.200 \\
0.243 \\
0.355 \\
0.686\end{array}$ \\
\hline Old $\dagger$ & $\begin{array}{l}\text { MAS } \\
\text { MAI } \\
\text { MOS } \\
\text { MIX }\end{array}$ & 0.071 & $\begin{array}{l}0.030 \\
0.143 \\
0.071\end{array}$ & $\begin{array}{l}0.121 \\
0.214 \\
0.071\end{array}$ & $\begin{array}{l}1.00 \\
0.849 \\
0.643 \\
0.786\end{array}$ & 0.077 & $\begin{array}{l}1.00 \\
0.231 \\
0.040\end{array}$ & $\begin{array}{l}0.154 \\
0.333 \\
0.120\end{array}$ & $\begin{array}{l}0.539 \\
0.667 \\
0.840\end{array}$ \\
\hline Very old $\dagger$ & $\begin{array}{l}\text { MAS } \\
\text { MAI } \\
\text { MOS } \\
\text { MIX }\end{array}$ & & & & & & & & $\begin{array}{l}1.00 \\
1.00 \\
1.00\end{array}$ \\
\hline
\end{tabular}

$*$ MAS $=$ "solid matrix, MAI $=$ matrix with inclusions, MOS $=$ mosaic, $\mathrm{MIX}=$ mixture.

$\dagger$ Young $=0-40$ yrs old; Mature $=41-100$ yrs old; Old $=101-150$ yrs old; and Very old $=>150 \mathrm{yrs}$ old

the understory make their way into the canopy, and some forest blocks at all three spatial scales move from the matrix with inclusion to the mosaic or mixture spatial structure. During the old and very old phases, black spruce, balsam fir, paper birch, and white cedar complete their expansion and invasion within the forest, and most blocks of all three sizes become mixtures (Fig. 11). Observed transitions among the four spatial structure categories (Table 8) confirm the general trend from solid matrix and matrix with inclusions as young stands to mosaics and finally mixtures as very old stands, for the 1934-1991 and 1961-1991 periods. All observed transitions in very old stands result in mixtures. Of those 1-ha blocks of forest that start out as solid matrices in 1934, some stay in the same category until 1991, while others change to matrices with inclusions or to mixtures (first row of young and mature transition matrices; Table 8 ). These varying pathways depend on the erratic distribution of canopy gap formation, which may miss some 1-ha blocks for decades, others lightly creating a few small openings that become inclusions, or create many openings resulting in a mixture. Thus, all blocks that are solid matrices will eventually make their way to the mixture category, but the timing will vary depending on the fine-scale spatial and temporal distribution of canopy mortality.

Proportions of blocks in each spatial structure type by age class (shown in Fig. 11 for 1991 only) are similar among the three dates $(1934,1961$, and 1991). Chisquare tests for each age class fail to reject the hypothesis that date of air photo and spatial structure category are independent for the 1-ha block size, $(P=$
$0.1-0.5$, except for the mature size class, where $P=$ $0.05-0.1$ ). Sample sizes are too small to do the same analysis for 4-ha and 16-ha blocks.

There are some differences in distributions among the structural types for the three spatial scales. At the 1 -ha scale, solid matrices occur $\approx 30 \%$ and $\approx 10 \%$ of the time in young and mature forests, respectively (Fig. 11). In our sample, solid matrices never occur at the 16-ha spatial scale. Mosaics are more likely to occur in young forests at the 16-ha spatial scale than at 1- or 4-ha spatial scale. Mixtures in old stands are more likely to occur at the 4- and 16-ha scales than at the 1-ha scale, whereas the proportion of 1-ha blocks that are mixtures almost catches up to that of 4- and 16-ha scales in very old stands. The foregoing points all illustrate that bigger blocks of forest undergo transition from matrix to mosaic to mixture slightly faster than smaller blocks. This result is expected because as canopy openings cause transition of bigger blocks to mosaics and mixtures, there could be 1-ha blocks embedded within a large block that by chance escape canopy disturbance and temporarily remain a solid matrix.

\section{DISCUSSION}

\section{Succession and the role of individual species}

Several studies in the boreal region have reported that differential growth rates among tree species are responsible for the appearance of compositional change in younger forests, and/or that differential longevity among species is responsible for change in canopy species composition in older stands (Dix and Swan 1971, 
Heinselman 1973, 1981a, Cogbill 1985). In the Seagull Lake area, however, directional change in canopy composition occurs for at least $190 \mathrm{yr}$ and is accompanied by (1) gradual loss of jack pine and aspen due to mortality without self replacement; (2) invasion of species new to a stand (balsam fir and white cedar; sometimes black spruce) at the time of canopy breakup; and (3) an increase over time in numbers of certain species that may be present from time of stand origin (usually black spruce and paper birch).

Bergeron and Dubuc (1989) found that all species are present in the $>5 \mathrm{~cm}$ dbh size class by stand age $50 \mathrm{yr}$ in northwestern Quebec boreal forests. The presence of a given species in a stand depends on spatial scale; a larger stand is more likely to have more species present at an earlier age. However, Bergeron and Dubuc's (1989) study plots were comparable in size to our two mapped plots ( 0.5 ha versus 0.53 and $0.56 \mathrm{ha}$ ). In the Seagull Lake study area, all species are not necessarily present in the canopy of young or mature stands ( $\leq 100$ years old). For example, balsam fir and white cedar have the first few canopy individuals old enough to produce seed at stand age $130 \mathrm{yr}$ on the Fishook Island mapped plot. Balsam fir and white cedar apparently invade at random locations with a few individuals (e.g., Fishook Island plot; Fig. 6), which can then serve as a seed source over the next several decades for establishment of a new patch mosaic by the time the forest is very old (e.g., Threemile Island plot; Fig. 6).

The discussion so far has concentrated on species composition and appearance in the canopy. However, there is evidence that fire may eliminate some species, such as balsam fir and white cedar, and that a genuine invasion by seed occurs in many stands after the original cohort is established. For example, there were no balsam fir seedlings or trees in several stands $3 \mathrm{yr}$ after the 1976 fire shown in Fig. 1 (Heinselman 1981b), nor any on two plots 1 yr after the 1974 burn (Ohmann and Grigal 1981). On the 1971 Little Sioux Burn, which occurred on a site physiographically similar to our study area, there is still no balsam fir (understory or overstory) $22 \mathrm{yr}$ after fire (Slaughter 1994). Forests in all three burns just discussed had significant balsam fir components before the fires.

When balsam fir and white cedar invade and/or make their way into the canopy, the available canopy space is shared among species. Area occupied by black spruce and paper birch, which often are present first, contract to make way for invading balsam fir and white cedar. Transition probabilities for the two mapped plots (Table 6) serve as examples of: (1) a stand where balsam fir and white cedar are just beginning to invade (Fishook Island), each having a 5\% chance of replacing dying pines; and (2) a 193-yr-old stand (Threemile Island) where invasion by balsam fir and white cedar has progressed substantially, with probabilities of replacing dying pines at $20 \%$ for both species. Currently, it is not known whether the likelihood that balsam fir and white cedar will replace other species will continue to increase with stand age. Spruce budworm infestations may limit the ability of balsam fir to continually increase in dominance. A Markov analysis of successional stability based on the transition probabilities in Table 6 was not attempted because clearly, transition probabilities change with stand age, and not enough data have accumulated for transitions from paper birch and white cedar on both ground study sites, or for balsam fir at Fishook Island.

Foster and King (1986) found in Labrador boreal forests that paper birch invades after stand-killing fire. These birch stands are later invaded by conifers. Unlike the findings of Foster and King, paper birch in our study area is not the major hardwood species after fire. All of the young hardwood stands in the Seagull Lake area are heavily dominated by quaking aspen, with minor components of bigtooth aspen, balsam poplar, and paper birch. The vast majority of hardwood stocking in older stands is paper birch. In addition, the transition probabilities in Table 6 show that relatively shade-tolerant species such as black spruce and balsam fir are often succeeded by shade-intolerant paper birch (see Discussion: Mechanisms of succession for potential explanations of this phenomenon).

The literature has been ambiguous about the role of black spruce in the boreal forests, with some studies finding it is capable of continuous self replacement on upland sites both moist (Foster 1983) and xeric (Bergeron and Dubuc 1989), while others (Dix and Swan 1971) report that it is present in early successional stands and then declines. We find that black spruce can be both a pioneer after stand-killing fire (e.g., Fishook Island plot; Fig. 4), and replace itself or increase in abundance in old stands (e.g., both mapped plots in Fig. 4; Fishook Island plot, Fig. 9). The life history characteristics of black spruce are suited to a dual strategy. The species has semi-serotinous seeds, so that massive recruitment is possible after fire, and continual seed dispersal is possible in the absence of fire (Heinselman 1973). Black spruce is also shade tolerant, and capable of producing new seedlings by layering of branches that touch the forest floor moss layer, and new seedlings are capable of successful establishment on moss, so that a postfire mineral soil exposure is not necessary for new seedlings (L. E. Frelich, personal observation).

The red pine stand mapped on Threemile Island is even-aged in the sense that all individuals are part of one postfire cohort. No evidence was found here of multi-cohort red pine resulting from repeated light-intensity fire, as was reported for red pine stands by Frissell (1973), Heinselman (1973), and Bergeron and Brisson (1990). Our red pine stand is like a variant of jack pine forest, only with longer-lived trees. Succession to the same mixture of black spruce, balsam fir, paper birch, and white cedar mixture that succeeds jack pine 
is occurring in the red pine stand (Figs. 3 and 4), but because the red pine live longer, the rate of change is slower. The Threemile Island stand is near the lake, so that surviving individuals along the shore could have reseeded the area with red pine after the 1801 fire. This process apparently took 30 years, since the pines range in age (at height of $1.0 \mathrm{~m}$ ) from 160-190 yr. This is the same strategy that allows white pine to establish lake shore groves (Heinselman 1973, Frelich 1992). Thus, red pine is capable of both massive although slow recruitment after catastrophic fire documented here, and intermittent recruitment in multi-aged stands documented by other studies. This dual strategy allows it to coexist with both jack pine and white pine.

\section{Direction of succession and spatial scale}

Under the natural disturbance regime of intense fire, jack pine or aspen stands burned and were replaced by the same species (Heinselman 1973, 1981a, b). This fits the parallel succession model with little change in species composition of the trees, although both the structure of the forest and the species of herbaceous plants undergo cyclic change (Heinselman 1981a, $b$ ). Based on the landscape level analysis of the BWCAW by Heinselman (1973), parallel succession in tree species composition occurred at all spatial scales from individual tree to landscape.

This formerly predominant model of successional direction is now changing rapidly under the present fire frequency in the BWCAW. Stands such as Threemile Island that originated in 1801 are now entering a successional stage that was rarely seen in the BWCAW prior to 1910. Van Wagner (1978) found that a negative exponential function with mean of 50 years fit Heinselman's age structure data from remnant primary forests in the BWCAW for the period prior to 1910. If so, then the chance that a given point on the ground would survive 100,150 , and 200 years without stand-killing fires would be $13.5,5.0$, and $1.8 \%$, respectively. Currently, within the 168000 ha unlogged portion of the BWCAW mapped by Heinselman (1973), stands $>100$, $>150$, and $>200$ years of age occupy $\approx 62,14$, and $5 \%$ of the landscape, respectively. Nearly half of the forest $(\approx 48 \%)$ is in the 100 to 150 -yr-old category, and in absence of fire will make its way into the very old category over the next few decades.

Direction of succession under lower fire frequency is scale dependent. At spatial scales of 1-16 ha, succession converges on a mixture of black spruce, balsam fir, paper birch, and white cedar. At spatial scales of 0.01-0.1 ha, succession is divergent from jack pine and/or aspen to four separate patch types. Note that a commonly used plot size in vegetation analysis is 20 $\times 20 \mathrm{~m}$, or 0.04 ha. Using plots of this size might lead an investigator to the conclusion that there are four separate forest types in very old stands, after the pines are gone, while the use of large 1-ha plots and/or the point quarter system (e.g., Dix and Swan 1971, Cogbill
1985, Bergeron and Dubuc 1989) would lead to the conclusion that forests were mixed.

Besides being divergent or convergent, succession at the current time is also individualistic in two senses. First, with respect to spatial scale, one patch of 0.1 ha size may periodically switch from one of the four oldgrowth species to any of the others, leading to continuous unpredictable change over time. At spatial scales of 1-16 ha, successional direction is somewhat predictable - a mixture of four species results, although the proportions of the four may vary individualistically over time. Second, succession on the study area is individualistic with respect to timing and rate of succession in each stand. This depends on erratic timing of small canopy-killing disturbance. One can be sure that over 200 years, succession from jack pine to other species will occur, but not at which point(s) it will occur during that 200-year period.

A final point to consider is the scale-dependent difference between a mosaic and a mixture. What appears as a mixture on air photos, where the minimum resolution is $\geq 0.1$ ha, can be a mosaic on the mapped plots (Fig. 6). Air photos have a resolution problem; if the resolution could be increased, then a finer mosaic could be revealed. Thus, one could refer to the mosaics and mixtures in Figs. 2 and 11 as mosaics and fine mosaics. The ultimate "mixture" would occur when individual trees of different species were randomly mixed, so that there is no dependence of species of a given tree on its neighboring trees. This is not the case here, since the stem maps (Fig. 6) reveal multi-tree clumps that occupy most of the plot area.

\section{Mechanisms of succession}

Succession is mediated by two main factors on the Seagull Lake study area: (1) disturbance and (2) understory tolerance. Under a natural disturbance regime of catastrophic fire, little change occurs in canopy tree species composition, so that true canopy succession is held in check by disturbance. In the absence of fire, a different kind of disturbance-small canopy openings-becomes important. These openings set up a finescale mosaic (Figs. 6, 8, and 9) that simultaneously eliminates the pioneer pines (Fig. 10), converts evenaged stands to multi-aged stands (Fig. 4), and gives the old forests their characteristic spatial pattern and their texture on air photos (Fig. 11). Biotic interactions among tree species probably do not cause patch formation (sensu Frelich et al. 1993), because the relationship between overstory and understory abundance of a given species is weak (Fig. 7), and self replacement is weak in most cases (Tables 5 and 6).

Weak overstory-understory relationships found here contrast sharply with those in other forest types in the Great Lakes region. For example, in hemlock/sugar maple forests, each species strongly influences the nearby composition of the understory and subsequently the species that replace individual trees when they die. Bi- 


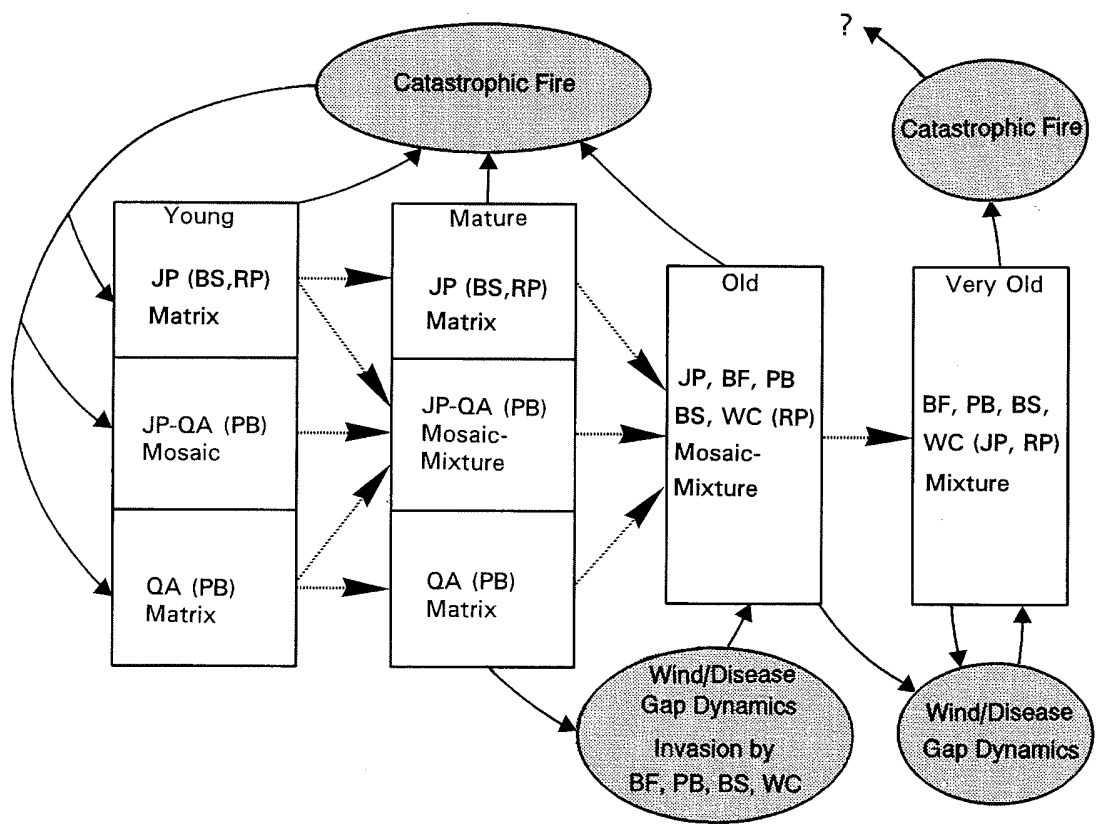

FIG. 12. Generalized summary of successional pathways in upland jack pine-aspen forest of the Seagull Lake area. Dotted arrows show pathways due to endogenous forces such as growth and self-thinning. Solid arrows show pathways caused by exogenous forces, which are noted in the shaded ovals. Species in parentheses are those occurring either at low abundance, or only occasionally, in a given forest type. $\mathrm{BS}=$ black spruce, $\mathrm{PB}=$ paper birch, $\mathrm{WC}=$ white cedar, $\mathrm{BF}=\mathrm{balsam}$ fir, $\mathrm{QA}$ $=$ quaking aspen, $\mathrm{RP}=$ red pine, and $\mathrm{JP}=$ jack pine

otic interactions in hemlock/sugar maple forests in some cases override disturbance as a cause of patch formation (Frelich et al. 1993, Frelich and Graumlich 1994).

The explanation for continued presence and/or increase in abundance in older stands of a species like paper birch-which is usually thought of as a pioneeris the subject of ongoing research. However, at this time it is reasonable to speculate that understory tolerance, rather than shade tolerance alone, is a major factor that drives succession in these forests. Canopy openings are quite large on our mapped plot (up to 30 $\mathrm{m}$ across) so that light is not limiting throughout an entire stand. For instance, on the Fishook Island mapped plot, paper birch seedlings (one to several years old) are found almost exclusively in areas where integrated light levels on average are between 25 and $50 \%$ of full sunlight, and black spruce seedlings, while common where light levels are $25-50 \%$, are also abundant in areas with light levels $<25 \%$ (M. B. Walters and P. B. Reich, unpublished data). Under controlled conditions of $25 \%$ full sunlight, paper birch seedlings rapidly outgrow black spruce, white cedar, and jack pine (P. B. Reich, M. G. Tjoelker, M. B. Walters, D. Vanderklein, and C. Buschena, unpublished data). In addition to light, other factors that relate to understory tolerance that will be the subject of future studies include ability to compete for rooting space, which could be very important on sites with extremely thin nutrient poor soils, and ability of a given species' seeds to ger- minate and become established on forest floor duff and moss cover.

\section{The process of succession and conclusions}

The demographic transition from even-aged stands of catastrophic fire origin to uneven-aged stands parallels a change from jack (occasionally red) pine and/ or aspen to the old-growth mixture of black spruce, balsam fir, paper birch, and white cedar (Fig. 12). Sometimes, as was the case on the Fishook Island mapped plot, black spruce enters the stand immediately after the fire along with jack pine, but is overtopped by the faster growing pine, so that black spruce makes its way into the canopy several decades later. The mechanism that moves this successional path forward is canopy openings caused by wind, insect, and disease, 10$30 \mathrm{~m}$ across on average, that gradually "chip away" at the relatively uniform canopy of pines and aspen. The main variable in succession is not whether each of these four species will invade, but when. Time of invasion depends on the timing of heavy windstorms that create canopy openings and the rate at which the original pines approach senescence. Canopy openings may be filled with one species or by more than one species; in the latter case the species form mono-dominant patches within the canopy opening. The dominant species within each patch is apparently independent of the overstory species that died when the opening was created or the species dominating surrounding patches. During succession, the spatial structure of the stands 
at the 1-16 ha scales generally changes from a matrix, solid or with inclusions, to a mosaic with relatively large patches that may be remnants of the extensive original matrix, and finally to a mixture with small patches (mean area $35 \mathrm{~m}^{2}$, maximum area $\approx 0.1 \mathrm{ha}$ ). Two patches side by side may coalesce to form one larger patch if by chance they are filled with the same species. Conversely, a new opening may occur that cuts across an old patch and be filled with a different species than the old patch. Small remnants of the old patch may remain.

Evidence for this successional process (Fig. 12) is: (1) all blocks of 1,4 , and 16 ha sizes that were followed over 56 years on air photos progress from jack pine/ aspen to the mixture of balsam fir, black spruce, white cedar, and paper birch; (2) disturbance chronologies for the two mapped plots show that pines are gradually replaced after stands attain an age of 90-100 years; (3) transition probabilities show that pines have substantial probabilities of being replaced by each of the oldgrowth species; (4) spatial autocorrelation analyses indicate patch sizes of 10-30 m for conspecific overstory trees, and for tree age; (5) there is no systematic association between overstory species and conspecific understory trees; (6) there is no positive spatial autocorrelation of species of large dead trees and species of nearby (0-5 m) small live trees; (7) small live trees of balsam fir, black spruce, white cedar, and paper birch are generally clustered. At this time, there is little evidence as to why a given canopy opening is filled by a given species. This is the subject of ongoing research by Reich and colleagues, in which factors affecting seed rain and environmental factors such as nutrients, light, water, and soil physical structure that influence germination and establishment of seedlings of all of the major boreal tree species are examined.

We conclude that most upland forest stands in the Seagull Lake area on similar soils follow the same successional path, although at different rates. Exceptions to this statement include white pine forests, which cover a small portion of the study area landscape $(<5 \%)$, mostly on small islands $(<20$ ha) and tips of peninsulas. These white pine stands have a different soil type, physiographic setting, and disturbance regime than the jack pine/aspen forests (Ohmann and Ream 1971, Heinselman 1973).

Apparently, postfire chronosequences in the Seagull Lake area over the last several decades have been relatively stable - the same successional sequence is reconstructed from a series of stands of different ages as from historical analysis of individual stands. All jack pine stands on sequential air photos over a 57-year period proceed along a pathway to a mixture of black spruce, balsam fir, paper birch, and white cedar. The same sequence can be reconstructed from stands of different ages as of 1991. Stable chronosequences have been assumed, but not tested, in many studies of boreal forest succession (e.g., Dix and Swan 1971, Grigal and
Ohmann 1975, Cogbill 1985, Bergeron and Dubuc 1989).

We cannot predict whether the chronosequence of stand development after fire will remain stable in the future. With continued low fire frequency, the jack pine stage may be reduced or eliminated, and aspen may fill the role formerly occupied by jack pine. There are two types of preliminary evidence for this. First, looking at a chronosequence of stands burned at the same date, older stands burned in 1976 were somewhat more likely to be replaced by aspen after burning than were younger stands (Table 7). Second, looking at young postfire stands at two different dates, $100 \%$ of 1-ha blocks examined on the 1934 air photos were dominated by jack pine (Fig. 10), whereas only $81 \%$ of 1-ha blocks $(n=$ 48) of young forest were dominated by jack pine while the remaining $19 \%$ were dominated by aspen as of 1991. It remains to be seen whether this conversion to aspen after fire is a long-term trend or a fluctuation. However, if it is a long-term trend and lack of fire leads to continuing loss of jack pine, then future options for vegetation management in this forest type within the BWCAW may be increasingly limited. Once jack pine seed source is lost in a given locality, reinstatement of burning may lead to aspen forests, and continued lack of fire will lead to the old growth mixture of balsam fir, black spruce, white cedar, and paper birch. Both of these options lead to vegetation types that were of minor importance in the presettlement BWCAW, and exclude the previously dominant mosaic of even-aged jack pine forests.

\section{ACKNOWLEDGMENTS}

This research was supported by the Wilderness Research Foundation and The National Science Foundation (IBN 9296005). Steve Lime, Wayne Wold, LLoyd Queen, and Marvin Bauer assisted with air photo interpretation and GIS analyses. Mike Chute, Jim Hager, Dave W. Peterson, José-Luis Machado, Dan Bahaudhin, and John Pukite assisted with the field work. Stephen Mulholland, of Superior National Forest, helped locate old air photos of the study area. Logistical support was provided by the Supervisor of Superior National Forest, staff of the Gunflint Ranger District, and by Jim Wiinanen and staff of Wilderness Canoe Base. Reviews of the manuscript were provided by James Ferrari and Dave W. Peterson. The late Bud Heinselman made available his lifelong collection of BWCAW data and provided advice on the design of the study.

\section{Literature Cited}

Ahlgren, C. E. 1969. Eighteen years of weather in the Boundary Waters Canoe Area, Quetico-Superior Wilderness Research Center. Minnesota Agricultural Experiment Station Miscellaneous Report 88, St. Paul, Minnesota, USA.

Baker, W. L. 1989. Landscape ecology and nature reserve design in the Boundary Waters Canoe Area, Minnesota. Ecology 70:23-35.

Bergeron, Y., and J. Brisson. 1990. Fire regime in red pine stands at the northern limit of the species range. Ecology 71:1352-1364.

Bergeron, Y., and M. Dubuc. 1989. Succession in the southern part of the Canadian boreal forest. Vegetatio 79:51-63.

Buell, M. F, and W. A. Niering. 1957. Fir-spruce-birch forest in northern Minnesota. Ecology 38:602-610. 
Carleton, T. J., and P. F. Maycock. 1978. Dynamics of the boreal forest south of James Bay. Canadian Journal of Botany 56:1157-1173.

Cattelino, P. J., I. R. Noble, R. O. Slatyer, and S. R. Kessel. 1979. Predicting the multiple pathways of plant succession. Environmental Management 3:41-50.

Christensen, N. L., and R. K. Peet. 1984. Convergence during secondary succession. Journal of Ecology 72:25-36.

Clements, F. E. 1936. Nature and structure of the climax. Journal of Ecology 24:252-284.

Cogbill, C. V. 1985. Dynamics of the boreal forests of the Laurentian Highlands, Canada. Canadian Journal of Forest Research 15:252-261.

Curtis, J. T. 1959. The vegetation of Wisconsin. University of Wisconsin Press, Madison, Wisconsin, USA.

Dansereau, P-R., and Y. Bergeron. 1993. Fire history in the southern boreal forest of northwestern Quebec. Canadian Journal of Forest Research 23:25-32.

Davis, M. B., S. S. Sugita, R. R. Calcote, J. B. Ferrari, and L. E. Frelich. 1994. Historical development of alternate communities in a hemlock-hardwood forest in northern Michigan, USA. Pages 19-39 in R. May, N. Webb, and P. Edwards, editors. Large-scale ecology and conservation biology. Blackwell, Oxford, England.

Dix, R. L., and J. M. A. Swan. 1971. The roles of disturbance and succession in upland forest at Candle Lake, Saskatchewan. Canadian Journal of Botany 49:657-676.

Drury, W. H., and I. C. T. Nisbet. 1973. Succession. Arnold Arboretum Journal 54:331-368.

Facelli, J. M., and S. T. A. Pickett. 1990. Markovian chains and the role of history in succession. Trends in Ecology and Evolution 5:27-30.

Foster, D. R. 1983. The history and pattern of fire in the boreal forest of southeastern Labrador. Canadian Journal of Botany 61:2459-2471.

Foster, D. R., and G. A. King. 1986. Vegetation pattern and diversity in S.E. Labrador, Canada: Betula papyrifera (birch) forest development in relation to fire history and physiography. Journal of Ecology 74:465-483.

Frelich, L. E. 1992. The relationship of natural disturbances to white pine stand development. Pages 27-37 in R. A. Stine and M. J. Baughman, editors. White pine symposium proceedings: history, ecology, policy and management. Minnesota Extension Service, University of Minnesota, St. Paul, Minnesota, USA.

Frelich, L. E., R. R. Calcote, M. B. Davis, and J. Pastor. 1993. Patch formation and maintenance in an old-growth hemlock-hardwood forest. Ecology 74:513-527.

Frelich, L. E., and L. J. Graumlich. 1994. Age class distribution and spatial patterns in an old-growth hemlock-hardwood forest. Canadian Journal of Forest Research 24:1939_ 1947.

Frelich, L. E., and G. L. Martin. 1988. Effects of crown expansion on evaluation of disturbance intensity in northern hardwood forests. Forest Science 34:530-536.

Frissell, S. S., Jr. 1973. The importance of fire as a natural ecological factor in Itasca State Park, Minnesota. Quaternary Research 3:397-407.

Gleason, H. A. 1927. Further views on the succession concept. Ecology 8:299-326.

Grigal, D. F., and L. F. Ohmann. 1975. Classification, description, and dynamics of upland plant communities within a Minnesota Wilderness Area. Ecological Monographs 45:389-407.

Heinselman, M. L. 1973. Fire in the virgin forests of the Boundary Waters Canoe Area, Minnesota. Quaternary Research 3:329-382.

- 1981a. Fire intensity and frequency as factors in the distribution and structure of northern ecosystems. USDA
Forest Service, Fire Regimes and Ecosystem Properties, General Technical Report WO-26:7-57.

- $1981 \mathrm{~b}$. Fire and succession in the conifer forests of northern North America. Pages 374-405 in D. C. West, H. H. Shugart, and D. B. Botkin, editors. Forest succession: concepts and applications. Springer-Verlag, New York, New York, USA.

Horn, H. 1974. The ecology of secondary succession. Annual Review of Ecology and Systematics 5:25-37.

Hubbell, S. P., and R. B. Foster. 1986. Biology, chance, and history and the structure of tropical rain forest tree communities. Pages 314-329 in J. Diamond and T. J. Case, editors. Community ecology. Harper and Row, New York, New York, USA.

Johnson, E. A. 1992. Fire and vegetation dynamics: studies from the North American boreal forest. Cambridge University Press, Cambridge, England.

Lippe, E., J. T. De Smidt, and D. C. Glenn-Lewin. 1985. Markov models and succession: a test from a healthland in the Netherlands. Journal of Ecology 73:775-791.

Lorimer, C. G. 1977. The presettlement forest and natural disturbance cycle of northeastern Maine. Ecology 58:139148.

Lorimer, C. G., and L. E. Frelich. 1989. A methodology for estimating canopy disturbance frequency and intensity in dense temperate forests. Canadian Journal of Forest Research 19:651-663.

Lorimer, C. G., L. E. Frelich, and E. V. Nordheim. 1988. Estimating gap origin probabilities for canopy trees. Ecology 69:778-785.

Ohmann, L. F., and D. F. Grigal. 1981. Contrasting vegetation responses following two forest fires in northeastern Minnesota. American Midland Naturalist 106:54-64.

Ohmann, L. F., and R. R. Ream. 1971. Wilderness ecology: virgin plant communities of the Boundary Waters Canoe Area. USDA Forest Service, North Central Forest Experiment Station, Research Paper NC-63.

Oliver, C. D. 1981. Forest development in North America following major disturbances. Forest Ecology and Management 3:153-168.

Pastor, J., R. H. Garner, V. H. Dale, and W. M. Post. 1987. Successional changes in nitrogen availability as a potential factor contributing to spruce declines in boreal North America. Canadian Journal of Forest Research 17:13941400.

Payette, S., C. Morneau, L. Sirois, and M. Desponts. 1989. Recent fire history of the northern Quebec Biomes. Ecology 70:656-673.

Peet, R. K. 1992. Community structure and ecosystem function. Pages 103-151 in D. C. Glenn-Lewin, R. K. Peet, and T. T. Veblen, editors. Plant succession: theory and prediction. Chapman and Hall, London, England.

Runkle, J. R. 1981. Gap regeneration in some old-growth forests of the eastern United States. Ecology 62:10411051

- 1982. Patterns of disturbance in some old-growth mesic forests of eastern North America. Ecology 63:15331546

Slaughter, K. W. 1994. Succession following forest fire in northeastern Minnesota; change in biomass and stand composition. Thesis. University of Minnesota, St. Paul, Minnesota, USA.

Smith, T., and M. Huston. 1989. A theory of the spatial and temporal dynamics of plant communities. Vegetatio 83:4969.

Sokal, R. R., and N. L. Oden. 1978. Spatial autocorrelation in biology. 1. Methodology. Biological Journal of the Linnean Society 10:199-228.

Van Wagner, C. E. 1978. Age-class distribution and the forest fire cycle. Canadian Journal of Forest Research 8:220-227. 
Watt, A. S. 1947. Pattern and process in the plant community. Journal of Ecology 35:1-22.

West, D. C., H. H. Shugart, and D. B. Botkin, editors. 1981. Forest succession: concepts and applications. Springer-Verlag, New York, New York, USA.

Whitney, G. G. 1986. Relation of Michigan's presettlement pine forests to substrate and disturbance history. Ecology 67:1548-1559.

Wilson, J. B., and A. D. Q. Agnew. 1992. Positive feedback switches in plant communities. Advances in Ecological Research 23:263-336. 